\title{
Grow - Store - Steam - Re-peat: Reuse of spent growing media for circular cultivation of Chrysanthemum
}

\author{
Bart Vandecasteele ${ }^{\mathrm{a},}{ }^{*}$, Liesbet Blindeman ${ }^{\mathrm{b}}$, Fien Amery ${ }^{\mathrm{a}}$, Christophe Pieters ${ }^{\mathrm{c}}$, \\ Sarah Ommeslag a, Koen Van Loo ${ }^{a}$, Caroline De Tender ${ }^{\mathrm{a}, \mathrm{d}}$, Jane Debode ${ }^{\mathrm{a}}$ \\ a Flanders Research Institute for Agriculture, Fisheries and Food (ILVO), Plant Sciences Unit, Burg. Van Gansberghelaan 109, 9820, Merelbeke, Belgium \\ b PCS Ornamental Plant Research, Schaessestraat 18, 9070, Destelbergen, Belgium \\ ' JoluPlant NV, Schierveldestraat 1, 8840, Staden, Belgium \\ d Department of Applied Mathematics, Computer Science and Statistics, Ghent University, Krijgslaan 281 S9, 9000, Ghent, Belgium
}

\section{A R T I C L E I N F O}

\section{Article history:}

Received 21 April 2020

2 September 2020

Available online 11 September 2020

Handling editor: Almeida

\section{Keywords:}

Recycling and reuse

Spent growing media

Circular economy

Steam treatment

Microbial inoculation

circular horticulture
Received in revised form

Accepted 6 September 2020

\begin{abstract}
A B S T R A C T
Substantially extending the life span of peat- and perlite-based growing media is a measure to increase the sustainability of soilless cultivation. The extraction of peat from pristine peatlands threatens these sensitive ecosystems and carbon sinks, meanwhile resulting in increased emissions of greenhouse gasses. Each batch of peat that is reused, results in a clear reduction in $\mathrm{CO}_{2}$ emissions and a lower impact on the climate. After using growing media for one cultivation, we aim at reusing the spent material as growing medium for another crop. Spent peat and perlite based growing media from strawberry and cucumber cultivation were upcycled after steam treatment. We tested the effectiveness of steaming to reduce phytosanitary risks. The hygienisation efficiency of the steam treatment was confirmed: plant pathogenic fungi, larvae of vine weevils and weed seeds added or already present before the process were killed by the steam treatment. As the upcycled spent growing medium already contained high nutrient levels, the fertilizer application in the reused growing medium should be reduced, especially for $\mathrm{P}$ and $\mathrm{K}$. Five indicators for assessing stability of the materials were used: $\mathrm{CO}_{2}$ flux measurements, oxygen uptake rate (OUR), biodegradation potential, mineral $\mathrm{N}$ content and risk for $\mathrm{N}$ immobilization. The spent growing media had a low decomposition rate and the release of nutrients in a leaching experiment was lower than for a fertilized peat-based growing medium, being a reference blend for open field cultivated Chrysanthemum. N mineralisation and P uptake were tested in an incubation and pot trial, respectively, and the upcycled spent growing medium was found to be an important source of plant-available $\mathrm{K}$ and $\mathrm{P}$. Steam treatment did not severely affect the microbial biomass and diversity of the spent growing media. Blending the steam-treated spent media with other materials or inoculating by a commercially available biocontrol fungus also had a limited effect, indicating that newly introduced microorganisms do not easily establish in steamed-treated spent growing media (SSGM). Acidification of the SSGM was achieved by a low dose of elemental $\mathrm{S}$. The steam-treated growing medium was tested for growing Chrysanthemum cuttings and plantlets. Spent growing media were not able to supply sufficient mineral $\mathrm{N}$, but the stored amounts of $\mathrm{P}$ and $\mathrm{K}$ in the media were sufficiently plant available for optimal crop growth. (c) 2020 The Author(s). Published by Elsevier Ltd. This is an open access article under the CC BY-NC-ND license (http://creativecommons.org/licenses/by-nc-nd/4.0/).
\end{abstract}

\section{Introduction}

Abbreviations: ASVs, amplicon sequence variants; GM, growing media; PLFA, phospholipid fatty acids; PFRV, Phosphorus Fertilizer Replacement Value, Ref: conventional growing media blend; SRF, slow release fertilizer; SGM, spent growing media; SSGM, steam-treated spent growing media (SSGM of Batch 1 => SSGM1); SSP, steamed spent perlite.

* Corresponding author. Institute for Agricultural and Fisheries Research (ILVO) Plant Sciences Unit B. Van Gansberghelaan 109, B-9820, Merelbeke Belgium

E-mail address: bart.vandecasteele@ilvo.vlaanderen.be (B. Vandecasteele).

\subsection{Reuse}

In the European Union, the total volume of growing media produced yearly (including home gardening) is around 35 million $\mathrm{m}^{3}$ (Schmilewski, 2017). The consumption of mineral wool, perlite and peat in professional horticulture is about $0.5,0.3$ and 16 million $\mathrm{m}^{3}$, respectively. Growing media manufacturing has an important 
environmental impact in Life Cycle Assessment (LCA) of several greenhouse production systems in Europe (Montero et al., 2009). The fate of spent growing media may further affect the environmental impact. When considering the end-of-life of used media (peat and garden waste compost) as soil amendments, Boldrin et al. (2010) found that growing media with 50 vol\% peat replacement by compost performed better with regards to global warming, nutrient enrichment and acidification versus fully peat-based growing media. Recchia et al. (2013) concluded that the use of the residual biomass in nurseries, including the chipping of wood for energetic reuse and the reuse of the spent growing medium in new blends, resulted in an important environmental impact reduction versus landfilling.

Growing media can affect plant growth, while plant growth and cultivation practices affect the potential for reuse of growing media due to the potential presence of plant roots, pathogens, residues of chemical plant protection, salts and/or chemical fertilizers in the growing medium at the end of the cultivation. In greenhouse cultivation, reuse of growing media is strongly encouraged because the disposal of growing media at the end of the growing season is a potential threat to the environment (Diara et al., 2012). Spent growing media can be directly recycled as soil improver, recycled as bulking agent for composting (Veijalainen et al., 2007; Viaene et al., 2017a), used as feedstock for energy (Kraska et al., 2018) and/or biochar production, or directly reused as growing medium with or without previous sanitation. The stability of the spent growing media is an important indicator for the reuse: highly degradable materials reused as growing medium might cause oxygen shortage in the medium and reduce the root development and plant growth (Brinton, 2001; Iglesias-Díaz et al., 2009). The stability of the SGM may thus determine its value in case of recycling.

\subsection{Hygienisation and blending}

Harmful, saprophytic and beneficial organisms are inhabiting growing media. Harmful organisms include weed seeds, but also plant and human pathogens such as Pythium and Phytophthora spp., and Legionella longbeachae, Salmonella enterica and Escherichia coli respectively (Carlile and Schmilewski, 2010). Seemingly harmless saprophytic fungi such as Peziza and Leucocoprinus spp. can form in severe cases a mycelium layer on the surface of the growing medium that limits water penetration and affects plant growth (Lohr et al., 2017). Cultivation in used growing media may dramatically increase the risks associated to root-borne pathogens and pests (Postma et al., 2008). Sanitation processes that are currently used in the growing media industry to reduce this risk include steaming, dry heat or friction heat treatment, composting, irradiation and solarisation. Cold or dry storage of spent growing media before reuse may be a less energy-demanding strategy for sanitation. A validation of the sanitation efficiency is important for each combination of technique, the material to be sanitized and the relevant pathogens and seeds (van Loenen et al., 2009).

The diversity and abundance of saprophytic and beneficial micro-organisms in growing media is generally much higher than harmful micro-organisms, but much less is known about the former group. Beneficial microbes can compete with pathogens, provide nutrients to the plants or act as a biostimulant. In general, growing media based on peat and inorganic constituents such as perlite have a low initial population of microorganisms, in contrast to the rich and diverse microbiome of growing media prepared from composted materials (Carlile and Wilson, 1990). Sanitation measurements, such as a steam treatment, may not only kill harmful organisms, but may also affect the total microbiome and allow the easy establishment of newly introduced microorganisms. These microorganisms can be introduced by blending with composted materials rich in microbial life or by adding commercially available products based on e.g., Trichoderma spp., inoculated on a carrier.

Reuse of spent media has been tested for several crops, with (e.g., Zucchi et al., 2017) or without (e.g., Baevre and Guttormsen, 1984) sanitation. Sometimes, clear positive effects on yield and/or plant health were found, e.g., sterilized growing media resulted in more vigorous strawberry plants with a reduced loss of yield compared to directly reused SGM (Zucchi et al., 2017). However, in other trials no effect on yield was found, as summarized by Diara et al. (2012).

\subsection{Physical properties, nutrients and salts}

Both the chemical and physical properties of spent growing media may be affected by the sanitation treatment, e.g. effects on total pore space and air porosity, easily available water, wettability, particle size and hydraulic conductivity of the medium (Giuffrida and Consoli, 2016; Urrestarazu et al., 2008). The effect may be related to the composition of the growing media blend (Zucchi et al., 2017). Materials in growing media may already act as a source of nutrients, independent of fertilizer addition or fertigation (Vandecasteele et al., 2018a). Spent growing media may have high nutrient concentrations (Baevre and Guttormsen, 1984). In some experiments with reused growing media, fertilizer application was not adapted for the nutrients enclosed in the spent media. Plant availability can be assessed before the cultivation by selective extractions (estimation of plant uptake, e.g. Baevre and Guttormsen, 1984) or during/after the cultivation by leaf analyses (assessing effective plant uptake, e.g., Jiménez et al., 2012 and Celikel and Caglar, 1999). Reuse of spent media has been tested for several crops, both with (Baevre and Guttormsen, 1984; Urrestarazu et al., 2008) or without (Jiménez et al., 2012; Celikel and Caglar, 1999; Yoon et al., 2007) adapted fertilizer supply. In the first case this results in an anticipation on the effect of nutrients and salts already enclosed in spent growing media (SGM). Acidification with elemental $\mathrm{S}$ is an effective strategy for reducing the $\mathrm{pH}$ of composts (e.g., Costello et al., 2019) and growing media blends (AmbergerOchsenbauer et al., 2017) through the activation of Thiobacillus and other sulfur oxidising species (García de la fuente et al., 2007), and may be needed in case SSGM have a higher than optimal $\mathrm{pH}$ for reuse as growing medium. Acidification with $S$ may affect other characteristics besides the $\mathrm{pH}$, i.e. a strong EC increase is expected, but nutrient availability and microbial biomass and activity may change as well ((Amberger-Ochsenbauer et al., 2017; Costello et al., 2019; García de la fuente et al., 2007).

\subsection{Aim}

We tested the effectiveness of steaming of peat-based growing media to reduce phytosanitary risks and the potential of SSGM to be reused as growing medium for ornamentals. The quality and stability of the processed growing medium was assessed based on both the physico-chemical and biological characteristics, and the need for optimizing the blend and the fertilizer dose was assessed. Different batches of spent growing media were tested before and after steam treatment, and after blending or acidification. These materials were incubated to assess (1) the N drawdown risk, (2) the $\mathrm{C}$ mineralisation and (3) the inoculation efficiency by a commercially available biocontrol fungus, together with biochemical, chemical $(\mathrm{pH}$, available and total nutrients) and microbiological (PLFA, metabarcoding) characterization. Reuse of the nutrients in the SGM was tested in plant trials with cuttings, and in greenhouse and open field cultivation. As far as we know, this is the first study to assess the abovementioned aspects together in one experiment, 
including the risk for nutrient leaching, and the effect of blending the SSGM with other materials. Some studies included the use of lower fertilizer doses when reusing growing media, which is also a goal in our study. This previous research focused on avoiding negative effects of too high salt and/or nutrient concentrations, while in our research we focused on the optimal use of the nutrients already present in the SSGM. In the latter case the supplied doses of fertilizer will probably be lower.

The hypotheses are:

- Spent growing media contain high loads of residual nutrients and salts, and have a high decomposition rate

- Steaming only has a limited effect on the physico-chemical characteristics but reduces the risk for pathogens and weeds

- Acidification has a distinct effect on the physico-chemical characteristics and on the microbiome

- Blending the SSGM with materials with a higher microbial biomass is needed to re-install and/or improve the microbiome

- SSGM have a high availability of macro-nutrients and a high risk for leaching of these nutrients

- SSGM have sufficient macro-nutrients for use in the cultivation of cuttings or the greenhouse or open field cultivation of Chrysanthemum

\section{Materials \& methods}

This study consists of five separate parts (Table S1; Fig. S1):

- (A) Spent growing media: Several batches of peat- or coir-based SGM were characterized and their characteristics were compared with green composts and feedstocks for growing media blends. For two batches of fresh SGM, the nutrient content and stability was assessed for the aboveground plant parts and the growing medium separately. Methods for chemical and stability characterization are described below. Green composts were collected in 2018 and 2019 at different composting plants in Northern Belgium.

- (B) The sanitation efficiency of the steam treatment process was tested three times, based on the survival of organisms and seeds in SGM (Fig. S2). We define the steam treatment process in this study as the combination of a short exposure to steam (1-2 min, $100{ }^{\circ} \mathrm{C}$ ) with a subsequent storage for $1 \mathrm{~h}$ with temperatures in the heaps of $70^{\circ} \mathrm{C}$ or more.

- (C) Four batches of spent growing media (code starting with SGM + batch number) were steam-treated (code starting with SSGM + batch number) at ornamental grower JoLuPlant (Staden, Belgium), i.e. Batch 1 on June 15, 2018, and the other batches (1 R, 2, 3) on March 12, 2019. These SSGM were analysed for chemical characteristics, $\mathrm{N}$ draw-down risk and stability, and tested for inoculation with a biocontrol fungus. The SSGM were compared with the SGM before steam treatment and with reference blends (REF), i.e., virgin growing media and materials used in these blends. One batch of spent perlite was steamed as well and used in the experimental blends for the cutting propagation.

- (D) 1 batch (SSGM1) was extensively tested in incubation ( $\mathrm{N}$ mineralisation) and pot trials ( $P$ fertilizer replacement value) and in a nutrient leaching experiment, and then compared with reference blends in plant trials. These reference blends were selected specifically for cutting propagation (3 blends), greenhouse ( 1 blend) or open air cultivation ( 2 blends) with the related relevant nutrient contents. One batch of spent perlite was steamed as well and used in the experimental blends for the cutting propagation.
- (E) After use as growing medium in the greenhouse, batch SSGM1 was steamed again (SSGM1R) for testing the effect of repeated reuse. Batch SSGM1 and SSGM1R were acidified with elemental $S$, and tested for inoculation by (a) blending with composts or other materials, or (b) with a biocontrol fungus, and then used for microbiological (PLFA, metabarcoding) characterization. The SSGM were compared with the SGM before steam treatment, the acidified SSGM, the materials used for blending, green composts and reference blends (REF), i.e., virgin growing media.

\subsection{Hygienisation efficiency of the steam treatment}

The sanitation effectiveness was tested 3 times during steaming operations at JoLuPlant (Staden, Belgium), i.e., on April 16, 2018, June 15, 2018 and March 12, 2019. To assess the effectiveness of the steam treatment process in terms of phytosanitary risks, (i) nylon bags were included in the process and (ii) cress tests with the steamed spent growing media were executed (Fig. S2). Nylon bags with 5 cellophane pieces $\left( \pm 1 \mathrm{~cm}^{2}\right)$ covered with Verticillium dahliae microsclerotia (resistant survival structures of a plant pathogenic fungus), 5 larvae of vine weevils (Otiorhynchus sulcatus F.), and 25 weed (Echinochloa crus-galli) and 100 garden cress (Lepidium sativum) seeds per bag were added before the steaming process and were recovered in the storage heaps. The survival was compared with bags with these organisms that were transported and stored at the same location during the test but were not steam-treated. The microsclerotia of $V$. dahliae strain Ve066 were produced on cellophane as described by López-Escudero et al. (2006). Survival of $V$. dahliae microsclerotia was checked by spreading the cellophane pieces over petri dishes containing MSEA (modified soil extract agar) medium (a semi-selective medium for $V$. dahliae, Harris et al., 1993) and incubated at $22{ }^{\circ} \mathrm{C}$. After 2 weeks, germination of the clusters of $V$. dahliae microsclerotia were counted under a binocular. Larvae of the black vine weevil were collected from naturally infested ornamental plants of a commercial grower and were visually checked for their survival. Seeds were put on wet filter paper and the number of sprouting seeds was counted after 1 week.

Cress (Lepidium sativum) is highly sensitive to Pythium causing damping off (Bongiorno et al., 2019). Therefore, cress seeds were sown in the 4 batches of the growing medium before and after steaming and in sterilized sand as negative control. The emerged cress seedlings were checked visually for damping off symptoms, plated on PARP (pimarcin, ampicillin, rifampicin, pentachloronitrobenzens) medium (a medium selective for Phytophthora and Pythium species, Jeffers and Martin, 1986) and incubated for 1 week at $22{ }^{\circ} \mathrm{C}$ in the dark. Fungal growth on the plates was examined under the microscope.

\subsection{Leaching test, $N$ mineralisation and $P$ fertilizer replacement of SSGM1}

The leaching of nutrients and the interaction with fertigation was compared for SSGM1 and the reference blend REF6. REF6 was selected as this is a commercial substrate for open air cultivation of Chrysanthemum in larger pots. The protocol is adapted from the soil leaching experiments of Vanden Nest et al. (2014), but no underpressure was needed for the columns with growing media as free drainage occurred (Full details: see Suppl. Method 1, Fig. S3). The growing medium was analysed before and after the leaching experiment (chemical analyses, see further). The $\mathrm{N}$ mineralisation of SSGM1 was assessed based on a 100 day-incubation trial (Viaene et al., 2017b and Suppl. Method2). The method for the assessment of the P fertilizer replacement value (PFRV) of SSGM1 relative to the 
$\mathrm{P}$ availability in triple superphosphate $\left(45 \% \mathrm{P}_{2} \mathrm{O}_{5}\right)$ and composts is described in Vanden Nest et al. (2020) and Suppl. Method2.

\subsection{Acidification and blending with other materials and a biocontrol fungus}

Two batches of SSGM were acidified with elemental sulfur (CAS product 7704-34-9, Fontaine-Beauvois). The materials were initially mixed with $0.5 \mathrm{~g} / \mathrm{L}$ elemental sulfur and the $\mathrm{pH}$ was monitored weekly, with an intended $\mathrm{pH}$ below 5 . If needed, additional elemental sulfur was added. The total dose of S supplied was 1.0 and $1.25 \mathrm{~g} \mathrm{S/L}$ for SSGM1 and SSGM1R, respectively.

The effect of blending SSGM with other materials on the bacterial and fungal microbiome was tested both for the SSGM of Batch1 (spring 2018) and R1 (spring 2019). Together with an unamended control, five materials (peat, bark compost, coco chips, coco chips inoculated with Trichoderma sp., green compost) were mixed at $10 \mathrm{vol} \%$ into $5 \mathrm{~L}$ of SSGM1 or $1 \mathrm{R}$ and stored for 2 weeks at room temperature. Each blend was mixed and sampled for PLFA (a subsample of $150 \mathrm{ml}$ was frozen at $-20{ }^{\circ} \mathrm{C}$ and then freeze-dried) and for metabarcoding analysis (a subsample of $50 \mathrm{ml}$ was frozen at $-20{ }^{\circ} \mathrm{C}$ ). The pure amendments were sampled with the same methodology at the onset of the second trial (SSGM1R) and analysed.

For assessing the inoculation efficiency by a biocontrol fungus, one $\mathrm{L}$ of each material was mixed with $1 \mathrm{~g}$ of commercial carrier with Trichoderma harzianum (Trianum ${ }^{\circledR}$ ) and stored in a $1 \mathrm{~L}$ PP container covered with parafilm. Materials were supplied with additional water depending on the initial DM content: $<50 \% \mathrm{DM}$ : $0 \mathrm{ml}, 50-60 \%$ DM: $50 \mathrm{ml}, 60-70 \%: 75 \mathrm{ml},>70 \%$ DM: $100 \mathrm{ml}$ water/L material. After 2 months incubation at $15{ }^{\circ} \mathrm{C}$ and $70 \%$ relative humidity (with a weekly and biweekly moisture correction in the first and second month, respectively), T. harzianum colonization of the materials was measured with a qPCR analysis as described in Lopez-Mondejar et al. (2010) \& Joos et al. (2020). To determine the initial inoculum added, $2 \times 250 \mathrm{mg}$ pure Trianum was analysed.

\subsection{Trials with chrysanthemum}

\subsubsection{Cutting propagation}

Chrysanthemum (Dendranthema $x$ grandiflorum) 'Rainbow Twist' cuttings were grown in paper plugs with a $3.5 \mathrm{~cm}$ diameter and $4 \mathrm{~cm}$ height in three commercial reference blends for cutting propagation (REF1, 2, 3, Table S2), and in three experimental blends, i.e., (a) $100 \%$ SSGM1, (b) $50 \%$ SSGM $1+35 \%$ steamed spent perlite $+15 \%$ peat and (c) $85 \%$ SSGM $1+15 \%$ steamed spent perlite. The test started on 30/08/18 with 4 replicates, and each replicate had 40 paper plugs and ended on September 18, 2018. Rooted cuttings were stored for the greenhouse trial, but 25 plugs per object were sampled and a composite sample was used for nutrient analysis.

\subsubsection{Greenhouse}

The rooted cuttings (24/replicate) from the previous trial on cutting propagation were transplanted in $1.5 \mathrm{~L}$ pots in a reference blend for greenhouse cultivation (REF4, Table S2) or in 100\% SSGM1. The trial started on $20 / 09 / 18$ in a greenhouse at $15^{\circ} \mathrm{C} / 15^{\circ} \mathrm{C}$ (day/ night) with additional lighting until $15 \mathrm{~h}$ day length, and plants were only supplied with water. From $01 / 11 / 18$ on, plants were grown at $21{ }^{\circ} \mathrm{C} / 21{ }^{\circ} \mathrm{C}$ (day/night) without additional lighting, and half of the pots were further supplied with water only (12/treatment), while the other part was fertigated weekly (200 ml/plant) with Kristalon witmerk (NPK 15-5-30) dosed at $1 \mathrm{~g} / \mathrm{L}(1.5 \mathrm{mS} / \mathrm{cm})$. Six plants per treatment were harvested for determination of flower and leaf biomass, and nutrient analysis. The trial was finished on $27 / 12 / 18$ and flowers and vegetative plant parts were weighed and sampled.

\subsubsection{Open field}

Two Chrysanthemum cultivars ('Sevilla Orange' and Salomon Surfer') were tested for 6 objects, i.e., 2 reference blends (REF5 and REF6, Tables S2) and 4 experimental blends (i.e., combination of two SSGM blends with two fertilizer strategies). The trial was run in three replicates per object and cultivar, and each replicate consisted of 18 pots. Plants were grown on a foil-covered container field to avoid rooting of the pots into the soil underneath and thus nutrient uptake was limited to the growing medium in the pots and the supplied fertilizers. REF5 had 50\% Baltic black peat, 30\% Baltic white peat and 20\% clay and had $1.3 \mathrm{~kg} / \mathrm{m}^{3}$ PG-mix (14-16-18 + trace elements) and $3 \mathrm{~kg} / \mathrm{m}^{3}$ Osmocote Pro 5-6 months (19-9$10+2 \mathrm{MgO}+\mathrm{TE})$. REF6 had $60 \%$ Baltic white peat, $20 \%$ green compost and $20 \%$ clay, with $2 \mathrm{~kg} / \mathrm{m}^{3}$ Osmocote Pro 5-6 mnd (19-9$10+2 \mathrm{MgO}+\mathrm{TE}$ ) and $1 \mathrm{~kg} / \mathrm{m}^{3}$ Selesia F2 (8-5-6) organic fertilizer. Two experimental objects consisted of $100 \%$ SSGM1, and the two others were a blend of $80 \%$ SSGM 1 and $20 \%$ of clay (being a regular additive in growing media for Chrysanthemum).

All experimental SSGM blends were supplied with a blendspecific dose of mineral $\mathrm{N}$ fertilizer (Tropicote $15.5 \% \mathrm{~N}+26.3 \%$ $\mathrm{CaO}$ ) to reach the same level of initial mineral $\mathrm{N}$ as in REF5, i.e., $243 \mathrm{mg}$ mineral N/L. Two strategies for fertilizer dose for the experimental blends were tested: a first strategy focused on only supplying extra $\mathrm{N}$ to supply the same total $\mathrm{N}$ dose as is supplied by the slow release fertilizer (SRF) in REF5, while the second strategy focused on adding, besides $\mathrm{N}$, the same amount of $\mathrm{P}, \mathrm{K}, \mathrm{Ca}, \mathrm{Mg}$ and micronutrients as supplied with the SRF in REF5. For the first strategy, two blends were additionally supplied with $\mathrm{NH}_{4} \mathrm{NO}_{3}$ (Amnitra $(18 \% \mathrm{~N}$ : 9\% NO3-N + 9\% NH4-N) in 3 fractions (19/06/19, $05 / 07 / 19$ and $16 / 07 / 19,50 \mathrm{ml} \mathrm{NH}_{4} \mathrm{NO}_{3}$ solution per pot, supplied in $1 \mathrm{~L}$ water) to reach a total dose of $570 \mathrm{mg} \mathrm{N} / \mathrm{L}$, the same dose of $\mathrm{N}$ as supplied as SRF in REF5. For the second strategy, two blends were supplied with a dose of $3 \mathrm{~kg} / \mathrm{m}^{3}$ Osmocote Pro 5-6 months (19-9$10+2 \mathrm{MgO}+\mathrm{TE}) \mathrm{SRF}$, i.e. the same dose of nutrients with SRF was supplied as for REF5. Plants were drip-irrigated with water in doses of $225 \mathrm{ml}$ per plant; the number of doses was based on the weather conditions and the global radiation. The trial started on 24/05/19 and was finished on 10/09/19 for 'Salomon Surfer' and on 17/10/19 for 'Sevilla Orange'. For statistical analysis, these objects were clustered in three groups per cultivar: (a) Reference blends with fertilizers, (b) SSGM1 + only mineral N supplied, and (c) SSGM1 + SRF supplied. 25 plugs per object and cultivar were sampled and a composite sample was used for nutrient analysis.

\subsection{Chemical analyses}

Methods for characterization of SGM, SSGM, reference materials/blends and green composts are based on European Standards developed by CEN, the European Committee for standardization. European Standard EN numbers refer to the specific standards. EC, $\mathrm{pH}_{(\mathrm{H} 2 \mathrm{O})}$ and $\mathrm{C}, \mathrm{Cl}, \mathrm{SO}_{4}, \mathrm{P}$ and mineral $\mathrm{N}$ of growing media were measured in a $1: 5 \mathrm{v} / \mathrm{v}$ water extract according to EN 13038, EN 13037 and EN 13652, respectively. Extracts were measured with a Dionex ICS-3000 ion chromatography (Dionex, Sunnyvale, CA), and $\mathrm{NH}_{4}-\mathrm{N}$ was measured with a Skalar San ++ Continuous Flow Analyser (Skalar, Breda, The Netherlands). As a relative indicator for available C, C was measured by a 5110 VDV Agilent ICP-OES (Agilent, Santa Clara, CA). K, Mg, Ca and P were extracted $(1: 5 \mathrm{v} / \mathrm{v})$ in $0.5 \mathrm{M}$ ammonium acetate (AmAc) buffered at $\mathrm{pH} 4.65$ (with $96 \%$ acetic acid) to assess the potentially plant-available concentrations available in the growing medium in the longer term. The $\mathrm{K}, \mathrm{Mg}, \mathrm{Ca}$ and $\mathrm{P}$ concentrations in the extract were measured by ICP-OES. 
Sample preparation for determination of total nutrient content, dry matter content, moisture content and laboratory compacted bulk density was executed according to EN 13040. Based on the moisture content of the material, the dry bulk density was calculated. Samples were dried for 4 days at $70{ }^{\circ} \mathrm{C}$, mechanically ground in a cross beater mill (SK100, Retsch, Haan, Germany) equipped with heavymetal-free grinding tools. Ground samples were stored in closed PP containers before analysis. Determination of OM content and ash ( $=100-\% \mathrm{OM})$ in the composts was done according EN 13039 by ashing in a Heraeus muffle oven at $450^{\circ} \mathrm{C}$. Total $\mathrm{N}$ concentration in the compost samples was determined according to the Dumas method (EN 13654-2) with a Thermo Scientific - FLASH 4000 total $\mathrm{N}$ analyser. Total $\mathrm{P}, \mathrm{Ca}, \mathrm{K}, \mathrm{Mg}, \mathrm{Na}$ and $\mathrm{Fe}$ concentrations were measured by ICP-OES after ashing $6 \mathrm{~h}$ at $450{ }^{\circ} \mathrm{C}$ and $1 \mathrm{~h}$ digestion at $100{ }^{\circ} \mathrm{C}$ with $7 \mathrm{~N} \mathrm{HNO}_{3}$.

\subsection{Stability assessment}

In this study we used five indicators for assessing stability of the materials: oxygen uptake rate (OUR), biodegradation potential, mineral $\mathrm{N}$ (i.e., $\mathrm{NH}_{4}-\mathrm{N}+\mathrm{NO}_{3}-\mathrm{N}$ ) content, risk for $\mathrm{N}$ immobilization (full details: see Suppl. Method 3), and $\mathrm{CO}_{2}$ flux measurements. OUR (expressed as $\mathrm{mmol} \mathrm{O}_{2} / \mathrm{kg} \mathrm{OM} /$ hour) is measured as the microbial activity in a closed Oxitop respirometer at $20{ }^{\circ} \mathrm{C}$ based on the method reported by Grigatti et al. (2011). The biodegradation potential was calculated as the holocellulose/lignin ratio $(\mathrm{HC} / \mathrm{L})$, based on the biochemical analysis with an Ankom 220 Fiber Analyser extraction unit according to Van Soest et al. (1991). The materials were tested for immobilization of mineral $\mathrm{N}$ (Vandecasteele et al., 2018b) by adding $350 \mathrm{mg} \mathrm{N} / \mathrm{L}$ material followed by incubation at $37{ }^{\circ} \mathrm{C}$ for seven days. $\mathrm{CO}_{2}$ emission was assessed by measuring $\mathrm{CO}_{2}$ flux 13 times during 30 days with a Licor LI-8100 Automated $\mathrm{CO}_{2}$ Flux System equipped with a soil flux chamber (LI-COR Biosciences, Lincoln, NE, USA). The cumulative $\mathrm{CO}_{2}$ release after 30 days was expressed as $\mathrm{mol} \mathrm{CO}_{2} / \mathrm{kg}$. A high $\mathrm{CO}_{2}$ release indicates a high decomposition activity in the material, thus a lower stability.

\subsection{PLFA and metabarcoding}

Total phospholipid fatty acids (PLFAs) were used to measure microbial biomass (one replicate/sample) and were isolated from $0.75 \mathrm{~g}$ freeze-dried material using phosphate buffer, chloroform and methanol at a 0.9:1:2 ratio. Phospoholipids separated by solid phase extraction were saponified to obtain free fatty acids, which were subsequently methylated using $0.2 \mathrm{M}$ methanolic $\mathrm{KOH}$ to form fatty acid methyl esters (FAME), which were analysed with a capillary gas chromatograph-flam ionisation detector (PerkinElmer Clarus 600, PerkinElmer, Waltham, USA) with a col-elite-2560 column (100 m length $\times 0.25 \mathrm{~mm}$ ID, $0.25 \mu \mathrm{m}$ film thickness, PerkinElmer).

PLFAs were identified by retention time using an external FAME and bacterial acid methyl ester (BAME) mix (Sigma Aldrich, St Louis, MO, USA) and quantified by a C19:0 internal standard.

Seventeen PLFAs were selected because of their use of biomarker fatty acids for six distinct microbial groups: Grampositive bacteria (i-C15:0, a-C15:0, i-C16:0, i-C17:0), Gramnegative bacteria (C16:1c9, C17:0cy, C19:0cy), bacteria (non-specific) (C14:0, C15:0, C16:0, C17:0, C18:0), actinomycetes (10Me-C16:0, 10Me-C18:0), fungi (C18:2c9,12) and mycorrhiza (C16:1c11), and summed up together with C18:1c9 to calculate total microbial biomass.

Metabarcoding was used to study the diversity and the composition of the bacterial and fungal microbiome of the spent growing media, composts and the reference materials (each material analysed in triplicate). DNA of the samples was extracted from $250 \mathrm{mg}$ sample with the DNeasy powersoil kit (Qiagen, Hilden, Germany) according to the manufacturer's instructions and eluted in $60 \mu \mathrm{l}$ Buffer. DNA was stored at $-20^{\circ} \mathrm{C}$ before use. Metabarcoding of the bacteria and fungi was done on the V3-V4 fragment of the $16 \mathrm{~S}$ rRNA gene and the ITS2 gene fragment, respectively (Illumina, San Diego, CA, USA). Library preparation, quality control and pooling was done as described in De Tender et al. (2016). Resulting libraries were sequenced using Illumina MiSeq v3 technology (2x300 bp) by Admera, United States, using $30 \%$ PhiX DNA as spike-in. Demultiplexing of the raw sequencing reads was done by the sequencing provider. Reads are available for download at the NCBI sequence read archive (SRA) under project number PRJNA624053. Primers were removed using Trimmomatic v0.32 (Bolger et al., 2014), adapters using cutadapt (Martin, 2011). Trimming, filtering, merging of the reads, dereplication, sorting, amplicon sequence variant (ASV) calling and chimera removal was done making use of the DADA2 algorithm v1.12 (Callahan et al., 2016). Briefly, all ambiguous bases were removed and the number of maximum expected errors for forward and reverse reads should not exceed three for bacterial sequences, and two for fungal sequences. Based on the quality profiles, the truncation length was set on $263 \mathrm{bp}$ and $240 \mathrm{bp}$ for the forward and reverse read respectively. A parametric error model was built for the forward and reverse read separately. After dereplication, reads were merged and an ASV table was built. To assign taxonomy to the resulting ASVs, the SILVA database v132 (Quast et al., 2013) for the V3-V4 $16 \mathrm{~S}$ rRNA gene sequences, and the UNITE database v8.0 (Kõljalg et al., 2013) for the ITS2 sequences was used as a reference. The resulting count table was used for statistical analysis.

\subsection{Data processing and statistics}

Effects of steaming on physico-chemical characteristics of SGM were tested with a paired $t$-test. Total leached amounts of nutrients between SSGM1 and REF6 were compared by a $t$-test. Nutrient uptake in the cuttings were compared by a $t$-test for the 3 reference blends versus the three experimental blends. For the greenhouse trial, a two-way anova was used for comparing both the effect of growing medium (SSGM1 vs. REF4) and fertigation (with vs. without) on nutrient uptake. For the container trial, two-way anova was used for comparing both the effect of cultivar and fertigation (reference vs. SSGM1 with mineral N vs. SSGM1 with SRF) on nutrient uptake (Statistica 13.5, Statsoft Inc.). Data were checked for normality and homogeneity of the variance.

Statistical analysis of metabarcoding data was done in $\mathrm{R}$, version 3.5.3 (R Core Team, 2019). ASV-tables were first filtered to remove low abundant counts. Only ASVs with a count of two in at least three samples were kept for analysis. Two heatmaps were constructed: one containing spent growing media before and after steaming, and before and after acidification; the other one containing the blends of the 2018 and 2019 experiments and the individual pure materials used in the blends. Pearson's correlation was calculated on the ASV-counts for each sample combination ( $R$ package Proxy, version 0.4.23) (Meyer and Buchta, 2019) and used to visualize the correlation between samples ( $\mathrm{R}$ package gplots version 3.0.1.1). Barplots to visualize the bacterial and fungal genera in the samples were created using $\mathrm{R}$ package Phyloseq (version 1.24.2) (McMurdie and Holmes, 2013). As input, unfiltered ASVtables were used. Filtering was done during a later stage to determine the most abundant genera to be visualised. A dissimilarity matrix was built, based on the Bray-Curtis dissimilarity index, from the ASV table as generated by DADA2, for both bacterial and fungal sequences. A PCoA-plot was constructed using the R package vegan (version 2.5.3) (Oksanen et al., 2010). The dissimilarity matrix was used to construct the PCoA-plot, comparing SSGM1R and the 
Table 1

Chemical characteristics and stability of different batches spent growing media from different crops and blends ( 1 replicate per material), and the average and min.-max. range (between brackets) for 15 green composts. Two batches (batch B and E) were split up in aboveground biomass versus spent growing medium, and the distribution of the nutrients between the growing medium and the plants was calculated: $\mathrm{P}_{\mathrm{ab}}$, $\mathrm{K}_{\mathrm{ab}}$, C $\mathrm{Cab}_{\mathrm{ab}}, \mathrm{N}_{\mathrm{ab}}$ : \% of total nutrient amount in the aboveground biomass, with $100 \%=$ total content (aboveground biomass + spent medium). Batch $\mathrm{F}$ contained plant biomass, but was not split up in spent medium versus aboveground plant parts. Min. $\mathrm{N}$ : mineral $\mathrm{N}=\mathrm{NO}_{3}-\mathrm{N}+\mathrm{NH}_{4}-\mathrm{N}$, OM: organic matter, DM: dry matter, $\mathrm{HC} / \mathrm{L}=$ holocellulose/lignin ratio, OUR: oxygen uptake rate, NA: not assessed, Nimmob.: \% $\mathrm{N}$ immobilization, $\mathrm{C}_{\text {water }}$ : water-extractable $\mathrm{C}$.

\begin{tabular}{|c|c|c|c|c|c|c|c|c|c|c|c|c|c|}
\hline \multirow[t]{2}{*}{ Crop } & \multirow{2}{*}{$\begin{array}{l}\text { Spent medium, } \\
\text { mix type }\end{array}$} & \multirow[t]{2}{*}{ Batch } & \multirow[t]{2}{*}{$\mathbf{P}$} & \multirow{2}{*}{$\frac{\mathbf{K}}{\mathrm{g} / \mathrm{kg} \mathrm{DM}}$} & \multirow[t]{2}{*}{ Ca } & $\mathbf{N}$ & OM & \multirow{2}{*}{$\frac{\mathbf{H C} / \mathbf{L}}{(-)}$} & \multirow{2}{*}{$\frac{\text { OUR }}{\mathrm{mmol} \mathrm{O}_{2} / \mathrm{kg} \mathrm{OM} / \mathrm{hr}}$} & $\mathrm{C}_{\text {water }}$ & $\min \mathbf{N}$. & \multirow{2}{*}{$\frac{\mathrm{CO}_{2} \text { release }}{\mathrm{mol} \mathrm{CO}_{2} / \mathrm{kg} \mathrm{OM}}$} & \multirow{2}{*}{$\frac{\text { N-immob. }}{\%}$} \\
\hline & & & & & & \multicolumn{2}{|c|}{$\% / \mathrm{DM}$} & & & \multicolumn{2}{|c|}{$\mathrm{mg} / \mathrm{l}$ substrate } & & \\
\hline \multirow[t]{9}{*}{ Strawberry } & Peat & A & 1.5 & 3.9 & 15.0 & 0.9 & 41.7 & 3.1 & 5.0 & 438 & 85.8 & NA & 7.2 \\
\hline & & B & 0.8 & 3.3 & 19.0 & 1.5 & 90.9 & 1.7 & 2.6 & 311 & 41.8 & 0.87 & NA \\
\hline & & C & 2.2 & 1.7 & 21.0 & 1.4 & 81.5 & NA & NA & NA & NA & NA & NA \\
\hline & & D & 0.8 & 3.1 & 22.0 & 1.2 & 89.4 & 2.0 & 1.9 & 313 & 127.3 & 0.48 & 17.1 \\
\hline & & $\mathrm{E}$ & 0.6 & 1.6 & 20.4 & 1.2 & 90.0 & 1.6 & 2.7 & 366 & 63.4 & 0.86 & 20.8 \\
\hline & & $\mathrm{F}^{\mathrm{a}}$ & 1.6 & 5.8 & 15.8 & 1.4 & 73.0 & 1.8 & 20.8 & 1183 & 103.1 & 3.12 & 32.1 \\
\hline & Peat/coco/perlite & G & 1.8 & 7.1 & 21.0 & 1.4 & 88.2 & 1.6 & NA & NA & 14 & NA & 72.6 \\
\hline & Coco & $\mathrm{H}$ & 2.7 & 4.1 & 16.0 & NA & 86.3 & 1.0 & NA & NA & NA & NA & NA \\
\hline & & I & 1.7 & 3.6 & 11.0 & 1.2 & 92.4 & 1.3 & 1.8 & 155 & 127.7 & 0.22 & 18.3 \\
\hline Cucumber & Coco & $\mathrm{J}$ & 0.5 & 3.0 & 14.0 & 1.1 & 92.2 & 1.1 & 1.5 & 115 & 145.8 & 0.65 & 7.1 \\
\hline \multirow[t]{2}{*}{ Tomato } & $\begin{array}{l}\text { Peat/coco/peat } \\
\text { moss }\end{array}$ & K & 6.8 & 9.5 & 35.0 & 1.6 & 78.6 & 1.8 & NA & NA & 409 & NA & 8.7 \\
\hline & $\begin{array}{l}\text { Peat/coco/peat } \\
\text { moss }\end{array}$ & $\mathrm{L}$ & 1.1 & 0.9 & 29.7 & 1.8 & 87.0 & 1.7 & 1.7 & 246 & 401.6 & 0.5 & NA \\
\hline Ornamentals & Peat & $\mathrm{M}$ & 1.5 & 4.9 & 26.4 & 1.3 & 56.0 & 1.1 & 0.4 & 521 & 121.2 & 0.25 & NA \\
\hline $\begin{array}{l}\text { Green composts } \\
\text { (15) }\end{array}$ & $\begin{array}{l}\text { Average } \\
\text { min.-max. range }\end{array}$ & & $\begin{array}{l}2.4 \\
(0.8-4.3)\end{array}$ & $\begin{array}{l}9.0 \\
(0.9-16.0)\end{array}$ & $\begin{array}{l}25 \\
(12-32)\end{array}$ & $\begin{array}{l}2 \\
(1.2-2.8)\end{array}$ & $\begin{array}{l}45 \\
(26-82)\end{array}$ & $\begin{array}{l}1.2 \\
(0.7-1.5)\end{array}$ & $\begin{array}{l}6.0 \\
(1.1-16.0)\end{array}$ & $\begin{array}{l}1735 \\
(190-3395)\end{array}$ & $\begin{array}{l}298 \\
(4-1069)\end{array}$ & $\begin{array}{l}2.0 \\
(0.3-5.6)\end{array}$ & $\begin{array}{l}28 \\
(0-63)\end{array}$ \\
\hline \multirow{3}{*}{\multicolumn{2}{|c|}{ Aboveground biomass (strawberry plants) }} & Batch & $\mathbf{P}$ & $\begin{array}{c}\mathbf{K} \\
\mathrm{g} / \mathrm{kg} \mathrm{DM}\end{array}$ & $\mathbf{C a}$ & \multicolumn{2}{|c|}{$\% / \mathrm{DM}$} & $\begin{array}{l}\mathbf{H C} / \mathbf{L} \\
(-)\end{array}$ & 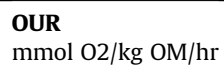 & $\begin{array}{l}\mathbf{P}_{\mathrm{ab}} \\
\%\end{array}$ & $\begin{array}{l}\mathbf{K}_{\mathbf{a b}} \\
\%\end{array}$ & $\begin{array}{l}\mathbf{C a}_{\mathbf{a b}} \\
\%\end{array}$ & $\begin{array}{l}\mathbf{N}_{\mathbf{a b}} \\
\%\end{array}$ \\
\hline & & B & 3.0 & 27.2 & 18.0 & 2.0 & 88.4 & 3.3 & 49 & 36 & 55 & 12 & 17 \\
\hline & & E & 3.6 & 30.1 & 25.3 & 2.5 & 86.4 & 2.3 & 102 & 48 & 75 & 17 & 25 \\
\hline
\end{tabular}

${ }^{\mathrm{a}}$ : contains fresh aboveground plant parts. 
blends for 2019 with a range of 15 green composts and 13 (feedstocks for) growing media blends. Total microbial biomass, obtained from PLFA-analysis, was fitted to the PCoA-plot.

\section{Results}

\subsection{Characteristics of spent growing media}

Different batches of spent growing media with variable composition and from different growers and crops were characterized (Table 1). The spent growing media still contain significant amounts of N, P, K and Ca and their nutrient content is within the range for green composts (Table 1). In comparison with these composts, spent growing media behaved in a specific way for the measured stability indicators. All spent growing media, except one, had a lower range for $\mathrm{CO}_{2}$ flux, \% $\mathrm{N}$ immobilization and for $\mathrm{HC} / \mathrm{L}$ than the composts, indicating a higher degree of stability and lower microbial activity than for composts.

There was only one spent growing medium with the aboveground crop biomass being included in the material (Batch F): this spent medium with plants dried out during storage in the greenhouse and was further stored dry before shredding. In these conditions, it was not possible for the plant material to degrade. For the other batches, aboveground plant material was removed from the spent growing media, or these residues decomposed during wet storage. In contrast to the other growing media, the spent medium with undecomposed leaves had higher values for all stability indicators, illustrating its lower stability.

For two batches of fresh spent growing media, the nutrient content and stability was assessed for the aboveground plant parts and the growing medium separately (Table 1). Although the dry mass of the aboveground plant parts is lower than $5 \%$ of the total dry mass, these parts contain $>30$ and $>50 \%$ of the total amount of $\mathrm{P}$ and $\mathrm{K}$, respectively, and are less stable than the growing medium with the roots, both for oxygen uptake rate (OUR) and for the $\mathrm{HC} / \mathrm{L}$ ratio. These data illustrate the lower stability and high $\mathrm{P}$ and $\mathrm{K}$ contents for the aboveground plant parts versus the spent growing medium.

\subsection{Sanitation efficiency of the steam treatment process}

A clear positive effect of the steaming process on plant pathogens and weed seeds was observed during the three tests (Table S3): V. dahliae microsclerotia, larvae of vine weevils, and weed (Echinochloa crus-galli) and garden cress (Lepidium sativum) seeds did not survive the steaming process, whereas survival in the not steam-treated bags was observed, illustrating the sanitation effectiveness of steam treatment. No larvae survived and no $V$. dahliae microsclerotia germinated on the MSEA plates. As no weed seeds emerged in the four batches of spent media before steaming, i.e., no germinative weed seeds were initially present in the SGM, the effect of steaming on weed seeds could not be assessed in the resulting SSGM, except for the seeds introduced with nylon bags. Cress seeds were grown on material from Batch 1 , $1 \mathrm{R}$ and 3 before and after steaming. The seedlings grown on these batches of SGM before steaming suffered from damping-off caused by Pythium (confirmed by microscopic identification of this fungus on the PARP plates), while no damping off or fungal growth on the PARP plates was observed for the material after steaming (Table 2). Batch SGM2 was the exception for this observation, which may indicate that the dry storage over longer periods may reduce the risk for damping off.

\subsection{Effect of steam treatment and acidification on physicochemical properties}

In general, the effect of steaming on chemical characteristics and stability is limited for the 4 batches (Table 2). For Batch 2, with the leaves in the material, steaming resulted only in a clear decrease for OUR, while the other stability indicators did not change. Only for C/ $\mathrm{N}$ there was a significant but small decrease due to the steaming process in the 4 batches (paired $t$-test, $\mathrm{p}<0.05$ ), while no significant changes were observed for the other parameters. Acidification resulted in lower $\mathrm{pH}$ and higher EC due to the conversion of elemental sulfur into sulphate, and reduced the $\mathrm{N}$ immobilization, the water-extractable $\mathrm{C}$ concentration, OUR and $\mathrm{CO}_{2}$ release, pointing at a higher stability after acidification (Table 2). In general, steaming had a limited effect on the AmAc-extractable nutrients (Table S4) for the 4 batches, while acidification of 2 batches resulted in a lower AmAc-extractable P concentration.

\subsection{Microbiology: effect of steaming, acidification and need for inoculation}

PLFA (microbial biomass) and metabarcoding (microbial diversity) were used to assess the effect of (a) steaming and acidification, (b) blending SSGM with compost, peat or coco chips and (c) inoculation with Trichoderma sp. on the microbiology of spent growing media.

The microbial biomass was compared with data for a range of (a) composts and (b) (feedstocks for) growing media blends. There was a clear but limited effect of steaming, i.e., a decrease of the total microbial biomass by 46 and $14 \%$ due to steaming for Batch 1 and $1 \mathrm{R}$, respectively (Table 3). The total microbial biomass in SGM was

Table 2

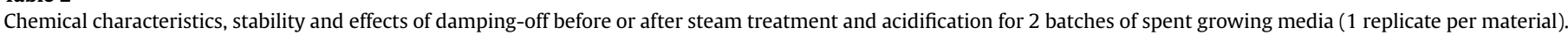

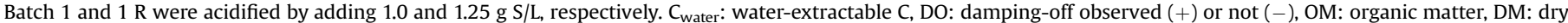

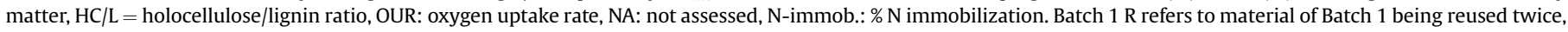
i.e., it was stored and steamed again after use of Batch 1 as growing medium in the greenhouse trial.

\begin{tabular}{|c|c|c|c|c|c|c|c|c|c|c|c|c|c|c|c|}
\hline \multirow[t]{2}{*}{ Batch } & \multirow[t]{2}{*}{ Treatment } & $\mathrm{pH}-\mathrm{H}_{2} \mathrm{O}$ & EC & $\mathrm{NO}_{3}-\mathrm{N}$ & $\mathrm{NH}_{4}-\mathrm{N}$ & $\mathrm{C}_{\text {water }}$ & OM & Total N & \multirow{2}{*}{$\frac{\mathrm{C} / \mathrm{N}}{-}$} & \multirow{2}{*}{$\frac{\mathrm{DM}}{\% / \text { fresh }}$} & \multirow{2}{*}{$\frac{\mathrm{OUR}}{\mathrm{mmol} \mathrm{O}_{2} / \mathrm{kg} \mathrm{OM} / \mathrm{hr}}$} & \multirow{2}{*}{$\frac{\mathrm{HC} / \mathrm{L}}{-}$} & \multirow{2}{*}{$\frac{\mathrm{CO}_{2} \text { release }}{\mathrm{mol} \mathrm{CO}_{2} / \mathrm{kg} \mathrm{OM}}$} & \multirow{2}{*}{$\frac{\mathrm{N}-\mathrm{immob} .}{\%}$} & \multirow[t]{2}{*}{ DO } \\
\hline & & - & $\mu \mathrm{S} / \mathrm{cm}$ & \multicolumn{3}{|c|}{ mg/L substrate } & \multicolumn{2}{|c|}{$\% / \mathrm{DM}$} & & & & & & & \\
\hline \multirow[t]{3}{*}{1} & Initial & 7.5 & 427 & 70 & $<5.0$ & 544 & 34 & 0.8 & 23.9 & 36 & 1.8 & 3.7 & 0.53 & 7.2 & + \\
\hline & Steamed & 7.5 & 448 & 70 & 7 & 947 & 32 & 0.8 & 22.5 & 35 & 2.4 & 3.6 & 0.58 & 0.4 & - \\
\hline & Acidified & 4.9 & 1088 & 10 & $<5.0$ & 154 & 38 & 0.7 & 31.2 & 35 & 0.5 & 4.0 & 0.15 & -17.0 & NA \\
\hline \multirow[t]{3}{*}{$1 \mathrm{R}$} & Initial & 8.0 & 293 & 8 & $<5.0$ & 318 & 37 & 0.8 & 26.6 & 59 & 1.0 & 2.7 & 0.30 & 19.5 & + \\
\hline & Steamed & 7.7 & 322 & 18 & 6 & 471 & 36 & 0.8 & 23.9 & 54 & 1.6 & 2.0 & 0.65 & 21.1 & - \\
\hline & Acidified & 4.5 & 1276 & 15 & 16 & 262 & 35 & 0.8 & 25.3 & 53 & 0.7 & 3.6 & 0.14 & 12.0 & NA \\
\hline \multirow[t]{2}{*}{2} & Initial & 6.9 & 520 & 71 & 32 & 1183 & 73 & 1.4 & 29.4 & 70 & 20.8 & 1.8 & 3.12 & 32.1 & - \\
\hline & Steamed & 6.9 & 512 & 72 & 38 & 880 & 68 & 1.4 & 27.6 & 57 & 5.8 & 1.6 & 3.24 & 29.3 & - \\
\hline \multirow[t]{2}{*}{3} & Initial & 7.6 & 300 & 52 & $<5.0$ & 293 & 31 & 0.6 & 27.4 & 35 & 3.7 & 2.6 & 0.72 & 6.1 & + \\
\hline & Steamed & 7.7 & 315 & 44 & 11 & 383 & 29 & 0.6 & 26.9 & 32 & 1.7 & 2.8 & 0.62 & 12.2 & - \\
\hline
\end{tabular}


Table 3

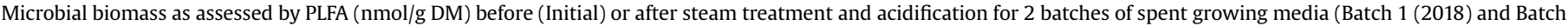

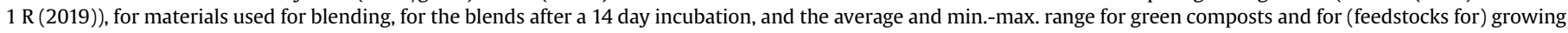

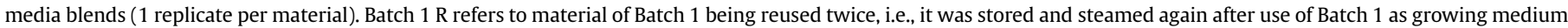
in the greenhouse trial (DM: dry matter).

\begin{tabular}{|c|c|c|c|c|c|c|c|}
\hline & Total non-specific bacteria & Total gram + & Total actino-mycetes & Total gram- bacteria & Total AM fungi & Total fungi & Total biomass \\
\hline \multicolumn{7}{|c|}{$\mathrm{nmol} / \mathrm{g} \mathrm{DM}$} & Effect steaming/acidification \\
\hline Batch 1, Initial & 92.6 & 99.1 & 15.6 & 51.7 & 29.9 & 9.2 & 300 \\
\hline Batch 1, Steamed & 61.7 & 53.0 & 8.6 & 24.0 & 7.9 & 6.2 & 163 \\
\hline Batch 1, Acidified & 89.6 & 44.5 & 6.2 & 74.2 & 5.7 & 3.9 & 227 \\
\hline Batch $1 \mathrm{R}$, Initial & 71.5 & 59.9 & 10.0 & 32.8 & 7.4 & 9.6 & 192 \\
\hline Batch $1 \mathrm{R}$, Steamed & 59.6 & 58.4 & 9.5 & 21.7 & 5.1 & 11.0 & 166 \\
\hline Batch $1 \mathrm{R}$, Acidified & 110.6 & 87.4 & 15.5 & 76.9 & 5.6 & 15.2 & 308 \\
\hline \multicolumn{8}{|c|}{ Materials used for blending } \\
\hline $\mathrm{Pe}$ & 37.3 & 37.0 & 5.5 & 12.9 & 1.3 & 30.0 & 150 \\
\hline Inoc. coco chips & 61.1 & 27.3 & 3.8 & 17.6 & 6.6 & 50.5 & 203 \\
\hline Coco chips & 72.4 & 47.4 & 4.8 & 26.6 & 7.7 & 36.1 & 221 \\
\hline Green compost & 130.7 & 193.7 & 47.1 & 27.7 & 9.3 & 19.4 & 424 \\
\hline Bark compost & 106.9 & 98.9 & 18.5 & 41.4 & 0.3 & 36.2 & 319 \\
\hline \multicolumn{8}{|c|}{ 2018: Blends for Batch 1} \\
\hline no additive & 52.1 & 46.8 & 7.9 & 22.7 & 8.0 & 6.1 & 146 \\
\hline+ Peat & 62.5 & 59.1 & 10.0 & 26.0 & 9.9 & 8.5 & 181 \\
\hline+ inoc. coco chips & 49.7 & 45.4 & 7.7 & 22.1 & 7.7 & 6.3 & 142 \\
\hline+ coco chips & 50.6 & 45.4 & 7.9 & 21.1 & 7.7 & 7.4 & 143 \\
\hline+ green compost & 48.4 & 48.7 & 9.2 & 18.7 & 7.5 & 6.3 & 140 \\
\hline+ bark compost & 55.7 & 51.2 & 7.8 & 24.7 & 7.9 & 7.0 & 157 \\
\hline \multicolumn{8}{|c|}{ 2019: Blends for Batch 1R } \\
\hline no additive & 64.1 & 55.0 & 7.7 & 27.4 & 5.6 & 12.1 & 175 \\
\hline+ Peat & 64.0 & 55.6 & 7.9 & 30.0 & 5.2 & 10.2 & 177 \\
\hline+ inoc. coco chips & 61.0 & 48.3 & 8.0 & 27.6 & 6.1 & 12.9 & 168 \\
\hline+ coco chips & 60.6 & 45.6 & 6.2 & 27.7 & 6.0 & 13.2 & 163 \\
\hline+ green compost & 76.2 & 76.0 & 13.9 & 33.6 & 7.1 & 10.3 & 218 \\
\hline + bark compost & 67.4 & 54.6 & 8.5 & 31.0 & 5.4 & 13.9 & 185 \\
\hline Green composts (15) & $102(46-201)$ & $162(54-317)$ & $40(9-75)$ & $30(8-64)$ & $7(0.5-22)$ & $33(2-91)$ & $367(144-658)$ \\
\hline Growing media blends (13) & $38(21-82)$ & $45(16-86)$ & $7(4-18)$ & $14(3-35)$ & $3(0.4-16)$ & $13(1-36)$ & $131(29-256)$ \\
\hline
\end{tabular}

similar to the growing media blends and lower than in the green composts. The bark and woody green compost used for blending with the SSGM had a higher microbial biomass than the other three materials (Table 3 ). In general, blending with the additives at a 10 vol\% rate did not clearly affect the total microbial biomass. Except for the total biomass of gram-negative bacteria and total AM fungi, the pure and blended SSGM have a lower microbial biomass than the average for the green composts, while the total microbial biomass is comparable as for the (feedstocks for) growing media blends. In contrast to steaming or blending, acidification had a clear effect on PLFA: there is a consistent increase in microbial biomass for the gram-negative bacteria after $\mathrm{S}$ addition, which includes the Thiobacillus species involved in the $\mathrm{S}$ oxidation.

Acidification strongly affected the bacterial microbiome diversity and composition, while the effect of steaming was rather limited, as shown by the clustering of acidified samples versus the samples before and after steaming in the heatmap (Fig. 1A). Data analysis at genus level indicated a strong increase in the relative abundance (\% of sequences \pm standard error) of Thiobacillus in the acidified samples: from $0.05 \pm 0.01 \%$ in the untreated samples to $41.0 \pm 1.1 \%$ in the acidified samples (results not shown).

In contrast to the bacterial microbiome, the fungal composition remained rather unaffected by acidification or steaming: no preferential clustering is observed, except for the heat treated samples of batch 1 versus the not heat treated samples (1 versus 1 init, Fig. 1B).

A limited effect of blending on the bacterial community is observed (Figure 2A and S4A). More specifically, for batch 1, only the coco chips blends ( $\mathrm{CI}$ and $\mathrm{CC}$ ) cluster separately from the unamended control (1_inc). For batch $1 \mathrm{R}$, all blends cluster together with the unamended control ( $1 \mathrm{R} \_$inc) and they are separated from the pure materials. Incubation did not change the bacterial microbiome for batch 1 ( 1 clusters together with 1 _inc), in contrast to batch $1 \mathrm{R}$ (where $1 \mathrm{R}$ clusters separately from $1 \mathrm{R}$ inc).

Blending changed the fungal community of the SSGM in 2019 (batch 1 R), but not in 2018 (batch 1) (Figure 2B and S4B). More specifically, for batch $1 \mathrm{R}$, the blends cluster together with the pure materials and are separated from the unamended control ( $1 \mathrm{R}$ inc). This is in contrast to batch 1 , where the blends cluster together with the unamended control (1_inc). Incubation changed the fungal community in both years.

Analysis of all samples at genus level in Fig. S4 reveals the absence of genera known to include human pathogens (such as Salmonella, Escherichia, Klebsiella, Shigella and Enterobacter) or plant pathogens that can infect the plant roots via the growing medium such as Verticillium, Rhizoctonia, Fusarium, Pythium, Phytophthora, Sclerotinia and Plasmodiaphora.

The changes in the fungal and bacterial microbiome by steaming or blending are rather limited compared to the range observed in composts and growing media blends (Fig. S5). Based on the PCoA plots of the bacterial and fungal diversity (Fig. S5), it is clear that the SSGM with or without blending are clustered separately from the composts and the (feedstocks for) growing media blends, indicating a clear difference in microbiome between these three groups, and a limited effect of blending of SSGM with other materials. The green composts are characterized by a higher total microbial biomass, which is related to the observed microbial diversity.

SSGM can be blended with other materials to affect the microbiome, but SSGM also can be inoculated with a biocontrol fungus. The inoculation efficiency by commercially available T. harzianum for SSGM1, $1 \mathrm{R}$ and 3 was comparable with or higher than 6 batches of composts, and similar to the range for 2 growing medium blends and 7 feedstocks for growing media (Fig. S6), but for SSGM2 the 
A
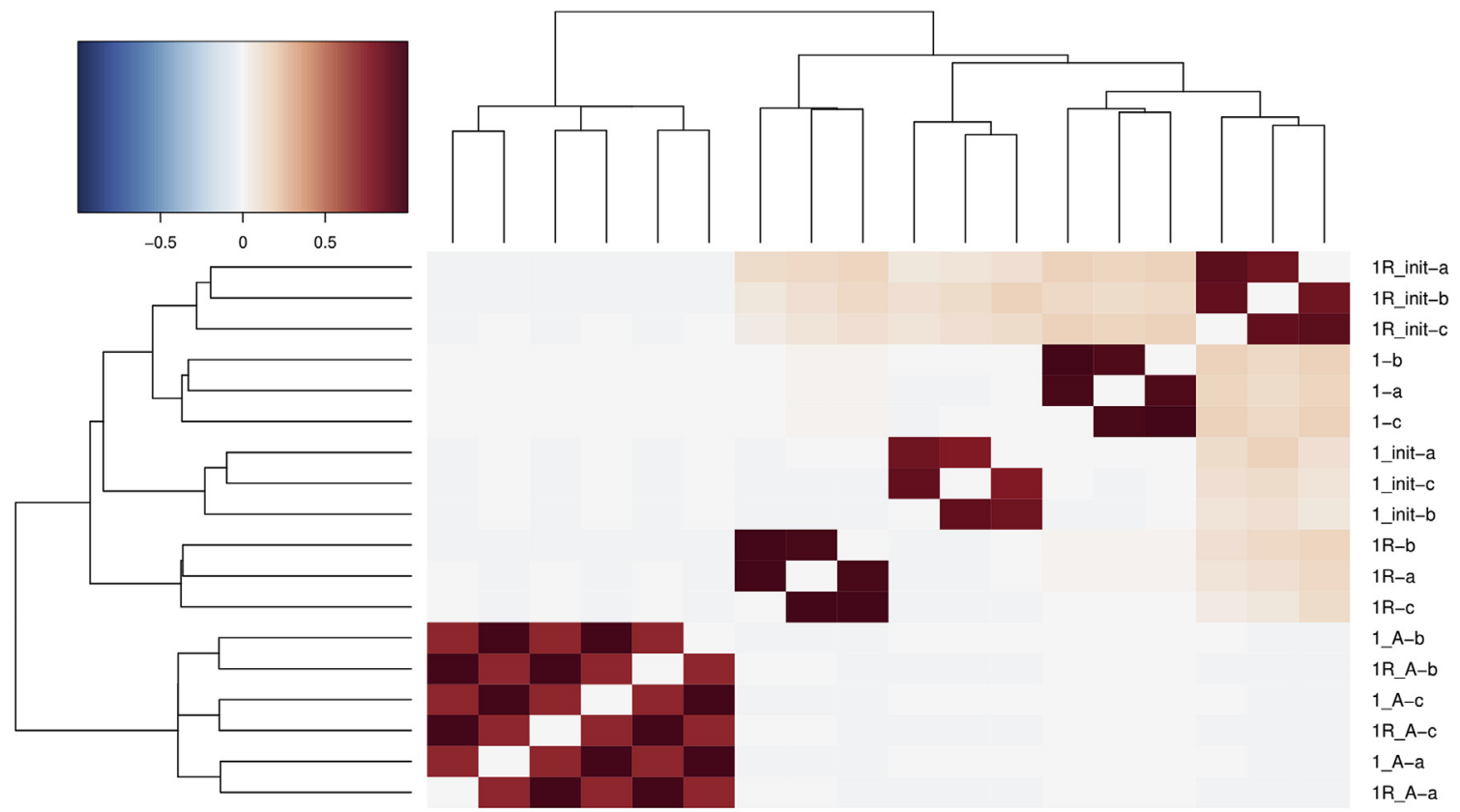

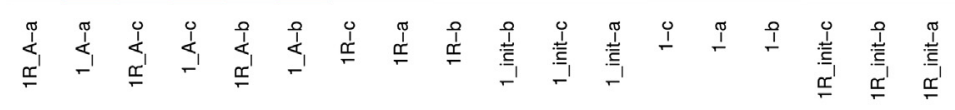

B

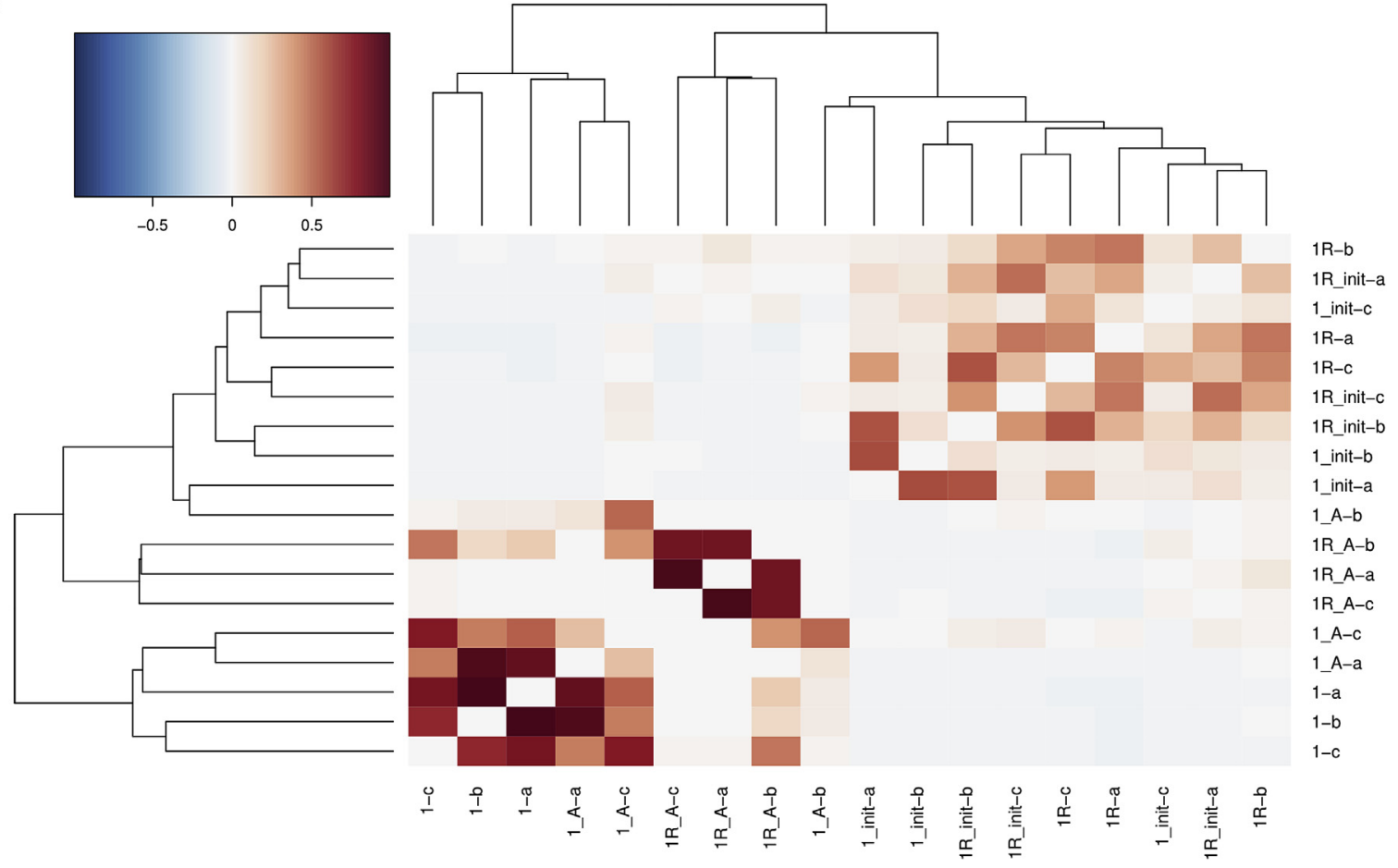

Fig. 1. Heatmap analysis of the Pearson correlation coefficient calculated from amplicon sequence variants table. The bacterial (A) and fungal (B) community composition of the spent growing media before (init) or after steaming, and after acidification (A) for Batch1 (1, batch 2018) and $1 \mathrm{R}(1 \mathrm{R}$, batch 2019) are illustrated. In total, three replicates per treatment ( $\mathrm{a}-\mathrm{b}-\mathrm{c}$ ) were analysed. Red represents a positive correlation, white no correlation and blue a negative correlation. Batch $1 \mathrm{R}$ refers to material of Batch 1 being reused twice, i.e., it was stored and steamed again after use of Batch 1 as growing medium in the greenhouse trial. The sequence of the samples is determined by the clustering of the amplicon sequence variants data, as visualised by the hierarchical cluster dendrogram on the X-and Y-axis. (For interpretation of the references to colour in this figure legend, the reader is referred to the Web version of this article.) 
A

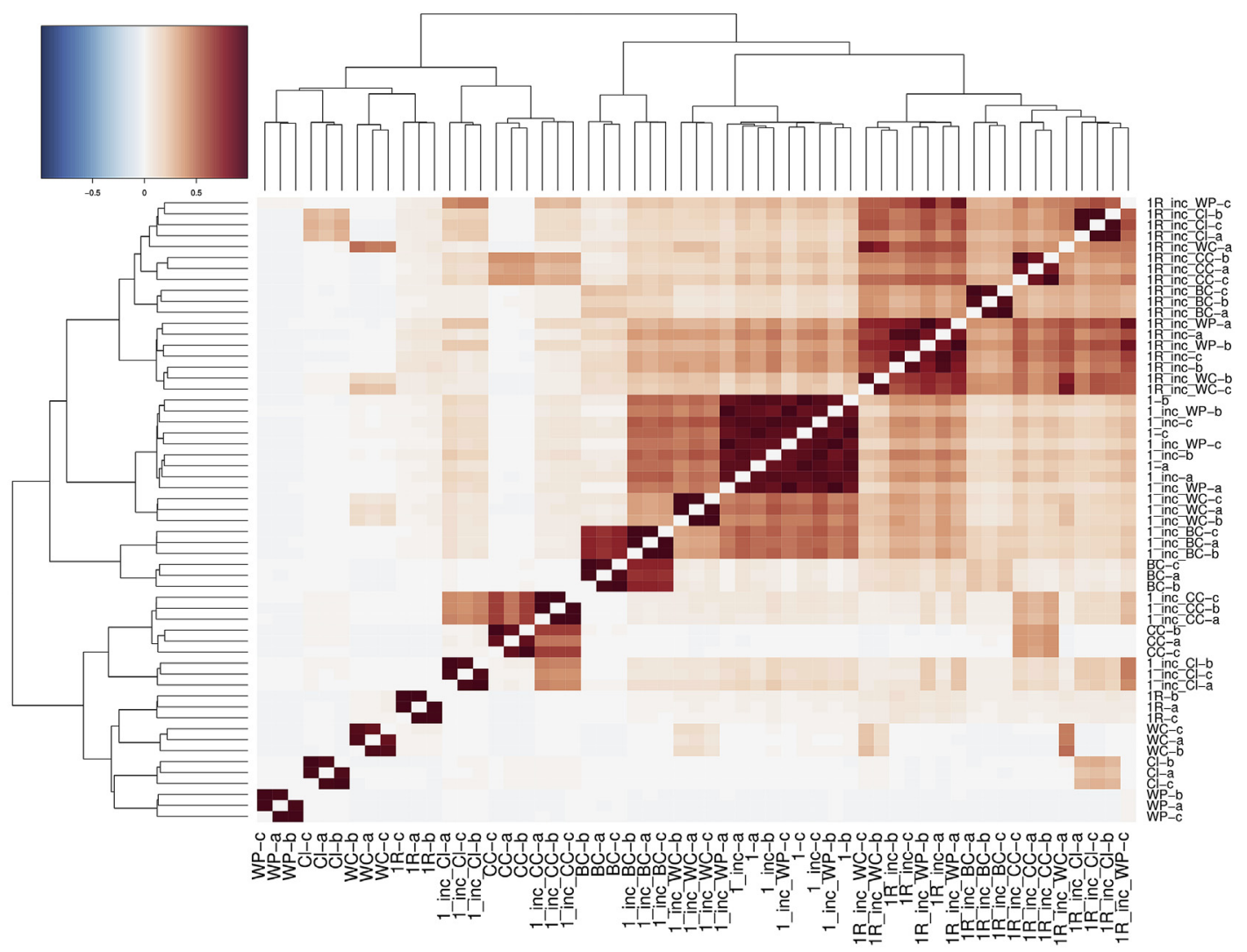

B

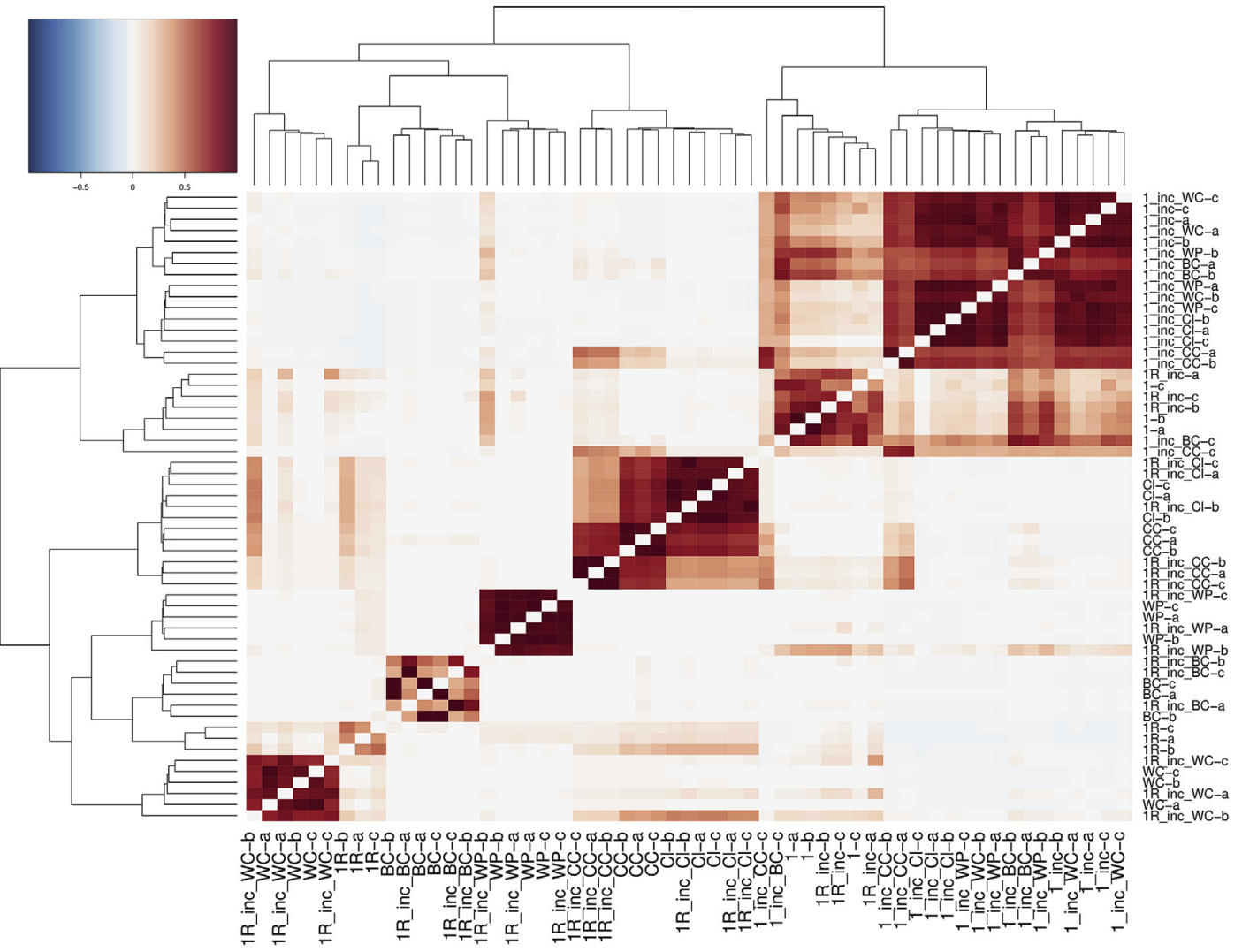


inoculation success was clearly lower than for the composts or the growing media.

\subsection{Nutrient release versus risk for nutrient leaching}

\subsection{1. $N$ immobilization or mineralisation}

There were differences in the risk for $\mathrm{N}$ immobilization between the 4 batches, with higher values for the less stable Batch 2 (Table 2). Steaming had a small effect on the risk for $\mathrm{N}$ immobilization, while acidification reduced this risk. As the risk for $\mathrm{N}$ immobilization was max. 30\%, this risk is rather limited. In contrast to the SSGM, growing media blend REF6 had a negative N immobilization of appr. $-40 \%$, indicating net $\mathrm{N}$ release from this blend. Long-term $\mathrm{N}$ mineralisation assessed in a standard incubation trial indicated low $\mathrm{N}$ mineralisation for the SSGM1, i.e. $2.5 \%$ of the total $\mathrm{N}$ content was mineralized after 100 days at $15{ }^{\circ} \mathrm{C}$. The initial \% mineral $\mathrm{N}$ versus the total $\mathrm{N}$ content was only $0.5 \%$ for SSGM1. $\mathrm{N}$ mineralisation was also assessed for four SSGM and REF6 after storage for at least 3 months at room temperature. After storage mineral $\mathrm{N}$ was mainly available as $\mathrm{NO}_{3}-\mathrm{N}$. For 2 SSGM there is a small immobilization of 18 (SSGM1) to 102 (SSGM2) mg N/L substrate, while for the other 2 SSGM a limited N release of 20 (SSGM3) to 36 (SSGM1R) mg N/L substrate was observed. In contrast, REF6 had a high $\mathrm{N}$ release of $>300 \mathrm{mg} \mathrm{N} / \mathrm{L}$ substrate.

\subsection{2. $P$ fertilizer replacement value (PFRV)}

The PFRV assessed in a standardised pot trial for the SSGM of Batch 1 was $65 \pm 14 \%$, which is comparable with the PFRV of $64-66 \%$ for composts with a Ca:P ratio $>20(n=3)$ and lower than the PFRV between 88 and $100 \%$ for composts with a Ca:P ratio $<11(\mathrm{n}=3)$ (Vanden Nest et al., 2020). The K fertilizer replacement value was not assessed in this trial, but based on the high AmAc-extractable $\mathrm{K}$ concentrations (Table S4) above the optimal range of 150-360 mg K/ L substrate, we expect a high $\mathrm{K}$ availability for plants. Based on these tests we conclude that the SSGM1 is characterized by a rather high plant-availability for $\mathrm{P}$, but $\mathrm{N}$ release is rather low.

\subsubsection{Nutrient leaching}

The release of nutrients was tested in a leaching experiment for SSGM1 and the reference blend REF6 (Table S2). Both SSGM1 and REF6 initially had high contents of $\mathrm{P}, \mathrm{K}$ and $\mathrm{Mg}$ with higher contents and a higher $\mathrm{pH}$ and EC for SSGM1. There was no significant difference in the volume of water passing through the growing media, being on average $4.4 \mathrm{~L}$ for the six columns (Table 4 ). The leaching phase with water was followed by a second phase with fertigation solution, with a $\mathrm{pH}$ on average 2 units lower than the water (Table 4).

The $\mathrm{pH}$ of the leached water is clearly and significantly higher for SSGM1 than for REF6, the EC is higher although the difference is not significant. The amounts of $\mathrm{N}, \mathrm{P}, \mathrm{Ca}, \mathrm{Mg}, \mathrm{Fe}, \mathrm{Al}, \mathrm{Mn}$, and $\mathrm{SO}_{4}$ leached during the water leaching part of the experiment were significantly higher for REF6 than for SSGM1, while higher amounts of $\mathrm{Na}$ and $\mathrm{Cl}$ were leached from SSGM1. No significant difference between both blends was observed for the total amount of leached $\mathrm{K}$. The same differences were also observed during the second phase in the experiment, but the total amount of leached $\mathrm{K}$ was now significantly higher for SSGM1 than for REF6 (Table 4).
At the end of the leaching experiment $\mathrm{pH}$, EC and available nutrients and salts were strongly reduced in the growing media compared to the initial situation (Table 4). The decrease is particularly very strong for $\mathrm{K}$, indicating a high $\mathrm{K}$ availability. SSGM1 had still a higher $\mathrm{pH}$ and $\mathrm{P}, \mathrm{Mg}$ and Ca content than REF6. The application of fertigation after leaching the growing media with water did not increase the content of nutrients and salts in the growing medium in comparison with the initial situation, which indicates a low sorption capacity for nutrients and salts of both SSGM and REF6. We conclude that nutrient leaching is significantly lower for SSGM1 than for REF6, which is evaluated as a positive characteristic, as the risk for nutrient losses from SSGM1 is lower, i.e., nutrients in the growing medium will be potentially longer available to plants for SSGM1 than for REF6. Although REF6 contained 20 vol $\%$ clay, this amendment did not result in lower leaching of nutrients versus the SSGM.

\subsection{Plant growth and nutrient uptake}

The reuse of SSGM for ornamentals including the assessment of the potential to reuse the nutrients in the spent growing medium was tested in three plant trials with Chrysanthemum (Dendranthema $x$ grandiflorum), i.e., during rooting phase of cuttings and cultivation in greenhouse and open field conditions.

\subsubsection{Cuttings}

Rooting in the blends was normal, both for the references and for the SSGM (results not shown). There was a significant higher content and uptake of P, K (Table S5) and $\mathrm{Na}$ (results not shown) for the blends with SSGM compared to the three reference blends for cutting propagation. Cuttings grown in the SSGM had taken up 1.5 times more $P$ and twice as much $K$ then the references REF1, 2 and 3. There was no significant difference for $\mathrm{N}$ uptake and plant biomass between SSGM and reference substrates.

\subsubsection{Greenhouse}

Plants grown on the SSGM had a more compact shape and a significantly lower DM biomass than for the reference substrate (Table S5). The compact shape is an advantage, as this may reduce the treatment dose with growth regulators. The $\mathrm{N}$ and $\mathrm{K}$ contents in the leaves for the SSGM without fertigation were significantly lower than for the other treatments. Slightly lower $\mathrm{Ca}, \mathrm{Mg}$ and $\mathrm{P}$ contents (Table S5) and clearly lower Na contents (results not shown) were measured for the SSGM. $\mathrm{N}$ contents in the leaves are below the deficiency threshold for Chrysanthemum (as reported by de Kreij et al., 1992) for the SSGM without fertigation, and Ca and $\mathrm{Mg}$ are below the optimal range for the SSGM. K contents were higher when fertigation was supplied, both for the SSGM and the reference substrate. Fertigation also resulted in significantly higher $\mathrm{Ca}, \mathrm{Mg}$ and $\mathrm{P}$ in the leaves, and foliar concentrations for SSGM with fertigation were in the optimal range for $\mathrm{Ca}, \mathrm{Mg}, \mathrm{P}$ and $\mathrm{N}$ and above the optimal range for $\mathrm{K}$ (Table S5).

We conclude that the SSGM without additional fertigation supplied sufficient $\mathrm{P}$ and $\mathrm{K}$ while the $\mathrm{N}$ supply is too low for optimal Chrysanthemum growth in greenhouse conditions. The $\mathrm{N}$ uptake was $40 \%$ and $20 \%$ lower for leaves and flowers, respectively for the SSGM without fertigation versus the reference.

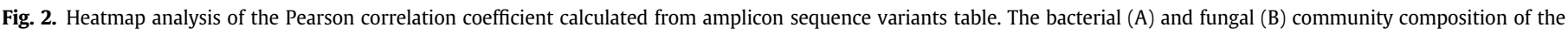

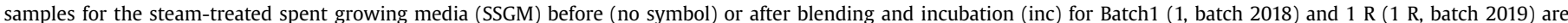

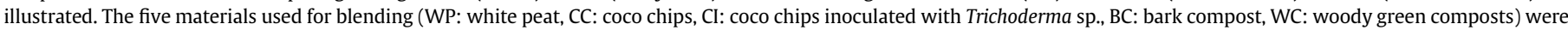

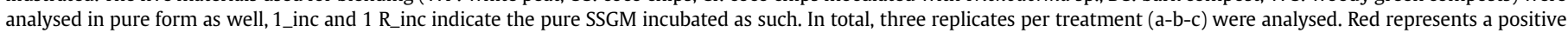

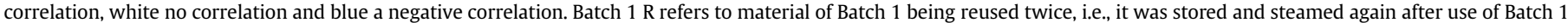

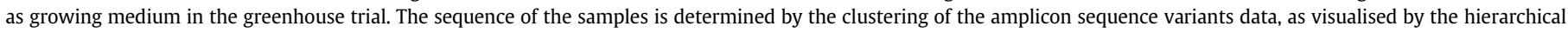
cluster dendrogram on the X- and Y-axis. (For interpretation of the references to colour in this figure legend, the reader is referred to the Web version of this article.) 
Table 4

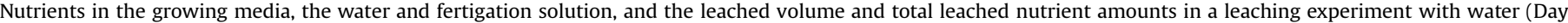

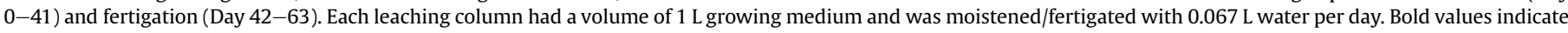

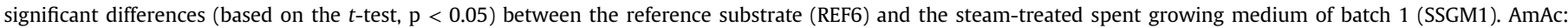
ammonium acetate extractable nutrients, n: number of replicates. Values in parentheses denote standard deviations.

\begin{tabular}{|c|c|c|c|c|c|c|c|c|c|c|c|c|c|}
\hline \multicolumn{14}{|c|}{ Growing media characteristics before and after the leaching experiment } \\
\hline Treatment & $\mathrm{n}$ & Time & $\mathrm{pH}-\mathrm{H}_{2} \mathrm{O}$ & EC & $\mathrm{NO}_{3}-\mathrm{N}$ & $\mathrm{NH}_{4}-\mathrm{N}$ & P-AmAc & K-AmAc & Ca-AmAc & $\mathrm{Mg}-\mathrm{AmAc}$ & $\mathrm{SO}_{4}$ & $\mathrm{Na}$ & $\mathrm{Cl}$ \\
\hline & & & - & $\mu \mathrm{S} / \mathrm{cm}$ & \multicolumn{9}{|c|}{$\mathrm{mg} / \mathrm{L}$ substrate } \\
\hline steam-treated & 1 & before & 7.5 & 448 & 70 & 7 & 134 & 957 & 1917 & 354 & 197 & 112 & 124 \\
\hline reference & 1 & before & 6.1 & 369 & 40 & 67 & 87 & 648 & 1795 & 335 & 253 & 66 & 86 \\
\hline steam-treated & 3 & after & $6.6(0.3)$ & $185(34)$ & $27(8)$ & $<5$ & $108(1)$ & $289(43)$ & $1634(90)$ & $275(18)$ & $135(20)$ & $<25$ & $<10$ \\
\hline reference & 3 & after & $5.4(0.2)$ & $178(12)$ & $32(2)$ & $<5$ & $42(2)$ & $316(16)$ & $1184(14)$ & $189(10)$ & $133(20)$ & $<25$ & $<10$ \\
\hline \multicolumn{14}{|c|}{ Nutrient concentrations in the incoming water and fertigation of the leaching experiment } \\
\hline Treatment & $\mathrm{n}$ & & $\begin{array}{l}\mathrm{pH}-\mathrm{H}_{2} \mathrm{O} \\
-\end{array}$ & $\begin{array}{l}\mathrm{EC} \\
\mu \mathrm{S} / \mathrm{cm}\end{array}$ & $\mathrm{NO}_{3}-\mathrm{N}$ & $\mathrm{NH}_{4}-\mathrm{N}$ & $\mathrm{P}$ & $\mathrm{K}$ & $\begin{array}{l}\mathrm{Ca} \\
\mathrm{mg} / \mathrm{L}\end{array}$ & $\mathrm{Mg}$ & $\mathrm{SO}_{4}$ & $\mathrm{Na}$ & $\mathrm{Cl}$ \\
\hline Water & 12 & & 6.17 & 6.7 & 0.19 & $<0.23$ & 0.04 & 0.53 & 0.02 & 0.01 & 0.44 & 0.13 & 0.18 \\
\hline Fertigation & 6 & & 3.81 & 1399 & 27.7 & 49.8 & 54.1 & 218.2 & 0.5 & 22.1 & 339 & 2.9 & 2.6 \\
\hline \multicolumn{14}{|c|}{ Total volume and cumulative amounts of nutrients leached during the leaching experiment } \\
\hline Treatment & $\mathrm{n}$ & total days & $\begin{array}{l}\mathrm{pH}-\mathrm{H}_{2} \mathrm{O} \\
-\end{array}$ & $\begin{array}{l}\mathrm{EC} \\
\mu \mathrm{S} / \mathrm{cm}\end{array}$ & $\begin{array}{l}\text { Volume } \\
\text { L }\end{array}$ & Min. N & $\mathrm{P}$ & K & $\mathrm{Ca}$ & $\mathrm{Mg}$ & $\mathrm{SO}_{4}$ & $\mathrm{Na}$ & $\mathrm{Cl}$ \\
\hline steam-treated & 3 & 41 & $7.4(0.1)$ & $330(4)$ & 3.14 & $117(11)$ & $58(4)$ & $609(47)$ & $96(8)$ & $39(3)$ & $228(14)$ & $87(8)$ & $137(11)$ \\
\hline reference & 3 & 41 & $5.8(0.3)$ & $253(16)$ & 3.20 & $331(20)$ & $143(13)$ & $546(45)$ & $426(29)$ & $154(11)$ & $618(18)$ & $63(4)$ & $110(4)$ \\
\hline steam-treated & 3 & 63 & $6.6(0.1)$ & $1379(4)$ & 4.39 & $171(14)$ & $101(1)$ & $807(52)$ & $197(9)$ & $77(5)$ & $522(12)$ & $96(9)$ & $141(11)$ \\
\hline reference & 3 & 63 & $5.3(0.3)$ & 1365 (12) & 4.54 & $385(13)$ & $181(13)$ & $693(35)$ & $540(32)$ & $191(11)$ & $910(24)$ & $69(3)$ & $113(4)$ \\
\hline
\end{tabular}

Table 5

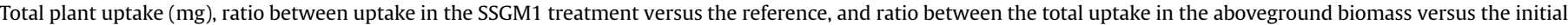

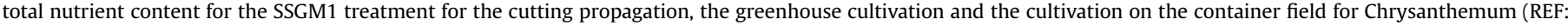
reference substrates, SSGM1: the steam-treated spent growing medium of batch 1).

\begin{tabular}{|c|c|c|c|c|c|c|c|}
\hline \multicolumn{8}{|l|}{ Totaal plant uptake } \\
\hline \multirow[t]{2}{*}{ Trial } & Substrate & Fertigation & $\mathrm{N}$ & $\mathrm{Ca}$ & K & $\mathrm{Mg}$ & $\mathrm{P}$ \\
\hline & & & \multicolumn{5}{|c|}{$(\mathrm{mg})$} \\
\hline cutting & REF1 & no & 6.6 & 2.5 & 8.8 & 0.7 & 0.9 \\
\hline \multirow[t]{3}{*}{ propagation } & REF2 & no & 7.1 & 2.3 & 7.4 & 0.7 & 0.9 \\
\hline & REF3 & no & 7.1 & 2.2 & 6.9 & 0.9 & 0.7 \\
\hline & SSGM1 & no & 7.6 & 2.3 & 15.9 & 0.7 & 1.4 \\
\hline \multirow[t]{2}{*}{ greenhouse } & REF4 & no & 588 & 247 & 903 & 77 & 121 \\
\hline & SSGM1 & no & 225 & 102 & 569 & 26 & 54 \\
\hline container & REF5 & no & 1975 & 1535 & 1734 & 527 & 467 \\
\hline \multirow{2}{*}{ Salomon } & REF6 & no & 1940 & 1594 & 2393 & 507 & 527 \\
\hline & SSGM1 & mineral $\mathrm{N}$ & 2998 & 1625 & 3000 & 567 & 492 \\
\hline container & REF5 & no & 2217 & 2121 & 1658 & 584 & 551 \\
\hline \multirow[t]{2}{*}{ Sevilla } & REF6 & no & 2012 & 2297 & 2126 & 621 & 574 \\
\hline & SSGM1 & mineral $\mathrm{N}$ & 2966 & 2345 & 2794 & 676 & 563 \\
\hline \multicolumn{8}{|c|}{ Ratio uptake SSGM1/reference } \\
\hline \multicolumn{2}{|c|}{ Trial } & Fertigation & $\mathbf{N}$ & Ca & $\begin{array}{c}\mathbf{K} \\
\%\end{array}$ & Mg & $\mathbf{P}$ \\
\hline \multirow{4}{*}{\multicolumn{2}{|c|}{$\begin{array}{l}\text { cutting propagation } \\
\text { greenhouse } \\
\text { container, Salomon } \\
\text { container, Sevilla }\end{array}$}} & no & 110 & 97 & 206 & 89 & 160 \\
\hline & & no & 38 & 41 & 63 & 34 & 44 \\
\hline & & mineral $\mathrm{N}$ & 153 & 104 & 145 & 110 & 99 \\
\hline & & mineral $\mathrm{N}$ & 140 & 106 & 148 & 112 & 100 \\
\hline \multicolumn{8}{|c|}{ Total plant uptake vs total content in growing medium initially } \\
\hline \multicolumn{2}{|l|}{ Trial } & Fertigation & $\mathbf{N}$ & Ca & $\begin{array}{c}\mathbf{K} \\
\%\end{array}$ & Mg & $\mathbf{P}$ \\
\hline \multirow{4}{*}{\multicolumn{2}{|c|}{$\begin{array}{l}\text { cutting propagation } \\
\text { greenhouse } \\
\text { container, Salomon } \\
\text { container, Sevilla }\end{array}$}} & no & 13 & 2 & 72 & 3 & 13 \\
\hline & & no & 10 & 3 & 66 & 4 & 13 \\
\hline & & mineral $\mathrm{N}$ & 44 & 15 & 117 & 26 & 40 \\
\hline & & mineral $\mathrm{N}$ & 44 & 22 & 109 & 31 & 46 \\
\hline
\end{tabular}

Significantly lower $\mathrm{N}$ and $\mathrm{Mg}$ and significantly higher K contents were measured in the flowers grown on SSGM1 without fertigation than for the other treatments. Ca and P contents in the flowers were significantly higher for REF4, independent whether plants were fertigated or not.
3.6.3. Open field

A significantly lower DM biomass was found for the early flowering cultivar 'Salomon Surfer' versus the late flowering cultivar 'Sevilla Orange', while the growing medium blend nor the fertigation did result in significant effects on DM biomass 
(Table S5). A cultivar effect was found for N, K and Ca, with higher N and $\mathrm{K}$ and lower Ca concentrations for cultivar 'Salomon Surfer'. There was a significant effect of growing medium on $\mathrm{Ca}, \mathrm{K}, \mathrm{P}$ and $\mathrm{Mg}$ concentrations, with significantly higher $\mathrm{K}$ concentrations and significantly lower Ca and Mg concentrations for the SSGM blends with SRF than for the reference blends (Table 5), pointing at higher $\mathrm{K}$ uptake when SRF was added to the SSGM. P concentrations were significantly higher for the reference blends than for the SSGM blends with mineral $\mathrm{N}$ fertilizer. The stored amounts of $\mathrm{P}$ and $\mathrm{K}$ in SSGM1 were thus sufficiently plant available for optimal crop growth.

\subsubsection{Reuse nutrients in the spent growing}

Data on total plant uptake for the 100\% SSGM objects without fertigation (cuttings and greenhouse trial) or with only mineral $\mathrm{N}$ fertigation (container trial) and for the references blends are summarized in Table 5. Both for the trial with cuttings and on the container field, the nutrient uptake in the plant for SSGM was comparable to the uptake for the reference blends, as the ratio was close to or higher than $100 \%$, indicating that in these trials nutrients in SSGM were plant-available in sufficient concentrations at the right moment, with underlying factors for plant uptake, including $\mathrm{pH}$, being optimal. For the greenhouse trial it was obvious that, due to $\mathrm{N}$ shortage, plants grown in SSGM without additional fertigation had a lower total nutrient uptake than the references in this trial. For the calculated relative plant uptake versus the total nutrient content of the initial SSGM, it is clear that the container trial had the highest nutrient use for $\mathrm{P}, \mathrm{K}, \mathrm{Mg}$ and $\mathrm{Ca}$ due to the higher plant biomass (141-200 g DM/pot, Table S5) in relation to the volume of SSGM per pot than for the cutting propagation $(<0,25 \mathrm{~g} \mathrm{DM} /$ cutting, Table S5) or the greenhouse trial (10-16 g DM leaves/pot, Table S5). The high \% nutrient use for $\mathrm{N}$ in the container trial can be accounted to the additional $\mathrm{N}$ fertigation in this trial. There is no direct reason for the very high \% nutrient use for $\mathrm{K}$ in this trial, being close to or higher than $100 \%$. It may indicate that the perlite in this blend may release additional $\mathrm{K}$ which was not measured during the total analysis method. During the container cultivation, there is a small decrease in AmAc-extractable P but a very clear reduction in AmAcextractable $\mathrm{K}$ (Table S4), with a higher decrease for $\mathrm{K}$ for cultivar Salomon, and a higher decrease for P for cultivar Sevilla, in line with the total $\mathrm{K}$ and $\mathrm{P}$ uptake of these cultivars (Table 5).

\section{Discussion}

\subsection{Slow decomposition and nutrient release}

The SGM in this study were characterized by low $\mathrm{N}$ release. The fact that mineral $\mathrm{N}$ is only very slowly released may indicate that there is no organic $\mathrm{N}$ or that the $\mathrm{N}$ is only limitedly available (very stable organic matter). In general, the mineral N content of the SGM is low, so $\mathrm{N}$ is mainly available as organically bound $\mathrm{N}$. The SGM in general had a high $\mathrm{C}: \mathrm{N}$ ratio which indicates that $\mathrm{N}$ will only be released in low amounts during $\mathrm{C}$ mineralisation. The low $\mathrm{N}$ release capacity of the SGM has been confirmed in our study. The overall C mineralisation is low for SGM, as based on the $\mathrm{CO}_{2}$ flux measurements, which was confirmed by the other stability indicators used, i.e., oxygen uptake rate, biodegradation potential (based on the $\mathrm{HC}$ / $\mathrm{L}$ ratio), and the risk for $\mathrm{N}$ immobilization. The $\mathrm{C}$ in peat-based SGM is thus highly stable, comparable to the high stability of pure peat. Due to the low $\mathrm{N}$ release from SGM, the risk for $\mathrm{N}$ leaching when reusing SGM is limited, as confirmed during the leaching experiment.

SGM based on peat, perlite and/or coir without aboveground plant biomass were characterized by a low decomposition rate, i.e., a high stability. Jackson et al. (2009) measured $\mathrm{CO}_{2}$ flux with another type of Licor equipment as the one used in our study, and they reported a flux of $3.5-30 \mu \mathrm{mol} \mathrm{CO}_{2} /\left(\mathrm{s} * \mathrm{~m}^{2}\right)$ for several materials, which is comparable to the range we measured for SGM, composts and growing media, i.e., $0.1-26 \mu \mathrm{mol} \mathrm{CO} /\left(\mathrm{s}^{*} \mathrm{~m}^{2}\right)$. Total $\mathrm{C}$ mineralisation can be expressed in different units. For the SGM, we measured a total $\mathrm{CO}_{2}$ flux of $0.2-0.7 \mathrm{~mol} \mathrm{CO} / \mathrm{kg}$ OM for the SGM without aboveground biomass, or, expressed as \% of $\mathrm{C}$ mineralized a range of $0.5-1.8 \%$ after 30 days at $20^{\circ} \mathrm{C}$, which is lower than the percentage of cumulative carbon loss of $2.3-3.4 \%$ for fresh or aged douglas fir bark after a 14 day incubation at $22{ }^{\circ} \mathrm{C}$ with $\mathrm{CO}_{2}$ traps (Buamscha et al., 2008), and comparable to the $0.3-1.5 \% \mathrm{C}$ mineralisation measured for peat moss, wood chips and pine bark growing medium after a 60 days incubation at $25^{\circ} \mathrm{C}$, assessed with $\mathrm{CO}_{2}$ traps (Boyer et al., 2012).

\subsection{No phytosanitary risks, low microbial biomass and low inoculation potential}

To avoid phytosanitary risks, sanitation of the SGM with the steam treatment in our study was found to be effective for this purpose. As our steam treatment procedure $\left(1-2 \mathrm{~min}, 100{ }^{\circ} \mathrm{C}\right.$ and storage in the heaps at $70{ }^{\circ} \mathrm{C}$ or more) was more than sufficient to reach the recommended time/temperature combination for heat treatment of biowaste $\left(70^{\circ} \mathrm{C}\right.$ for $1 \mathrm{~h}$, preferably by wet heat) (OEPP/ EPPO, 2008), all tested harmful organisms were killed, including plant pathogens, insect larvae and weed seeds.

Besides the differences in total microbial biomass, there were also differences in the ratio between groups between SSGM, green composts and (materials for) growing media blends. The gram + bacteria to gram-bacteria ratio may indicate a difference in stress tolerance (Uhlîrová et al., 2005). There was a clearly lower average value of this ratio for SSGM (2.0) than for green composts (7.8) and growing media blends (3.7), indicating a lower stress tolerance for SSGM, or the high water content of SSGM favoring gram- bacteria, as was observed for soils (Uhlî́rová et al., 2005). Microbial communities as assessed by DGGE were influenced not only by steam sterilization but also by growing medium type (Zucchi et al., 2017). Data of metabarcoding and PLFA in our study indicate a substrate-dependent effect on the structure of the microbial communities (as illustrated by the difference between composts, virgin (feedstocks for) growing media blends, and the blended SSGM), and a limited influence of the steam treatment. Besides the low decomposition rate indicating low microbial activity and the low PLFA indicating low microbial biomass, we also observed a limited effect of blending the SSGM with other materials and a colonization efficiency by the biocontrol fungus T. harzianum comparable with composts and virgin GM blends. Blending the SSGM with materials with a higher microbial biomass was not found to be effective to re-install and/or improve the microbiome. Blending other materials at higher rates in the SSGM may be more effective, although the limited change in microbial biomass may also indicate that the peat-based material is not able to support a higher microbial biomass. As acidification by elemental $\mathrm{S}$ resulted in stimulation of Thiobacillus, this can be considered as an indirect inoculation method. After acidification, we see a shift in the bacterial microbiome, and an increase in total microbial biomass, indicating a more pronounced effect of acidification by elemental $\mathrm{S}$ versus blending or inoculation. This might be related to the stimulation of the microbial activity due to the $S$ oxidation, while in case of blending materials the trigger for an increase in microbial activity and a chance in microbial biomass may be smaller or absent.

The high $\mathrm{OM}$ content and $\mathrm{C}_{\text {water }}$ of spent growing media (Table 2) may favour the activity of the bacteria or fungi involved in the acidification as these micro-organisms need a $C$ source, and our results indicate that the low microbial biomass was not a limiting 
factor for this process. Besides the increase in microbial biomass, acidification also resulted in a clear increase in the stability indicators OUR, water-extractable $\mathrm{C}$ and $\mathrm{C}$ mineralisation rate, together with an increase of the EC from 322 to 448 to 1088-1276, and a lower inoculation success with T. harzianum (Fig. S6). These EC values after acidification are rather high, acidified SSGM should thus preferably be mixed in a 50/50 vol\% ratio with materials low in EC. The acidified SSGM were not tested in our plant trials, so an assessment of the net effect of $S$ addition on plant growth cannot be made. In the plant trials we did not observe any adverse effects of SSGM1 without acidification: the higher PH in SSGM did not impair it's reuse as growing medium. The $\mathrm{pH}$ decrease of $2 \mathrm{pH}$ units in the SSGM was obtained with $S$ doses of $<1.5 \mathrm{~g}$ S/L SSGM, i.e. rather small doses compared to doses needed for acidifying composts: between 6 and $113 \mathrm{~g} \mathrm{~S} / \mathrm{L}$ compost was needed for a range of 10 compost types (Costello et al., 2019), and a dose of 8.5-12.4 g S per liter compost was supplied for 3 types of composts from vegetable crop residues for having a pH drop of 2 units (García de la fuente et al., 2007; Carrión et al., 2008).

\subsection{Reuse as GM and source of nutrients}

We observed high nutrient contents in a range of spent growing media, a range comparable with green composts. The effective reuse of these nutrients enclosed in composts (Vandecasteele et al., 2018a) or spent growing media is determined by the availability of these nutrients for plant uptake. Soumaré et al. (2002) observed that $50 \%$ of $\mathrm{P}$ and $36 \%$ of $\mathrm{K}$ was plant-available in a spent peat growing medium, while the SGM was high in C (39\%), with a high C/ $\mathrm{N}$ of 40.8 , indicating a potential risk for $\mathrm{N}$ immobilization. Plantavailability was assessed with ammonium acetate, the method we also used to test the spent growing media. Our measurements in the pot trials confirmed the high $\mathrm{P}$ and $\mathrm{K}$ plant availability, while the risk of $\mathrm{N}$ immobilization was low, and the $\mathrm{N}$ release from the SSGM was not sufficient for optimal plant growth. We also observed slow leaching for the nutrients in the SSGM, although the other macro-elements than N in the SSGM were plant available to a high degree in the pot trial with Chrysanthemum. We conclude from the plant trials and the related calculations that SSGM can supply sufficient $\mathrm{P}, \mathrm{K}, \mathrm{Ca}$ and $\mathrm{Mg}$ for cultivation of ornamentals, thus allowing to optimally reuse the nutrients already present in the SSGM. Additional mineral N should however be supplied to optimize the plant growth and the related P, K, Ca and Mg uptake. The nutrients in SGM have potential for substituting commercial mineral fertilizers in growing media, with consequent benefits on eutrophication and other environmental impacts by avoiding the productions of $\mathrm{N}$ and $\mathrm{P}$ fertilizers (Boldrin et al., 2010). It was found that $\mathrm{N}$ release from SSGM was too slow for optimal plant growth: these media can be the source of sufficient P, K, Ca and Mg while N should be added in sufficient amounts and in directly available form. In contrast, REF6 had initially already high mineral $\mathrm{N}$ concentrations, and a high $\mathrm{N}$ release of $>300 \mathrm{mg} \mathrm{N} / \mathrm{L}$ substrate (as tested during storage). This explains the high amount of mineral $\mathrm{N}$ leached from REF6, while the $\mathrm{N}$ release and leaching from SSGM1 was clearly lower.

Some studies included the use of lower fertilizer doses when reusing growing media, while other studies applied the regular fertigation as for virgin growing media. The EC of spent media doubled during reuse without adapted fertigation versus the virgin ones (Zucchi et al., 2017). Baevre and Guttormsen (1984) and Yoon et al. (2007) already observed a strong increase in the nutrient content and availability of spent growing media in case of repeated use versus the virgin blends, and concluded that the concentration of the nutrient solution should be lowered to reduce the salinity for the next season (Baevre and Guttormsen, 1984).
Previous research focused on avoiding negative effects of too high salt and nutrient concentrations, while in our research we focused on the optimal use of the nutrients already present in the SSGM. Reuse or recycling of these nutrients and the organic matter in the growing medium at the end of the culture is another step towards a more sustainable cropping system. The Chrysanthemum trials have clearly shown that adapted fertigation or fertilizer application is important when reusing growing media. For the cultures tested here, we found that additional nutrient supply in case of reuse of spent media could even be reduced to supplying only mineral $\mathrm{N}$. Mineral $\mathrm{N}$ can be supplied as mineral fertilizers (e.g., $\mathrm{NH}_{4} \mathrm{NO}_{3},\left(\mathrm{NH}_{4}\right)_{2} \mathrm{SO}_{4}$ ) or through organic fertilizers with a fast $\mathrm{N}$ release, e.g., blood meal or chitin. These amendments may affect the pH of the growing medium (Vandecasteele et al., 2018b) so both $\mathrm{N}$ release and effect on $\mathrm{pH}$ are relevant for selecting the $\mathrm{N}$ source. By reducing the amounts of nutrients accumulated in the used growing media through reduced fertigation or fertilizer amendment, the potential for recycling or reuse of the growing media is further increased. The next step is to reduce the nutrient accumulation during the first use of a growing medium: this is the first opportunity to reduce the amount of nutrients supplied by fertigation and to avoid unbalanced nutrient supply and unnecessary nutrient losses early in the life span of growing media.

\section{Conclusion}

From this study we conclude that:

- Spent growing media contain high loads of residual nutrients and salts (within the range of green composts), but have a low decomposition rate

- Steaming only has a limited effect on the physico-chemical characteristics but reduces the risk for pathogens and weeds

- Acidification has a limited effect on the physico-chemical characteristics but a strong effect on the microbiome

- Blending the SSGM with materials with a higher microbial biomass is not needed to re-install and/or improve the microbiome

- SSGM have a high availability of macro-nutrients but a low risk for leaching of these nutrients

- SSGM have sufficient macro-nutrients other than $\mathrm{N}$ for use in the cultivation of cuttings or the greenhouse or open field cultivation of Chrysanthemum; additional supply of a $\mathrm{N}$ source is needed.

\section{CRediT authorship contribution statement}

Bart Vandecasteele: design and Supervision of the project, Statistical analysis, first draft was written by, finalization of the document was done by all authors, Statistical analysis. Liesbet Blindeman: design and execution of the chrysanthemum experiment. Fien Amery: design and execution of the leaching experiment. Christophe Pieters: design and execution of the steaming experiment. Koen Van Loo: and design and execution of the leaching experiment: chemical and PLFA characterization: SO, and design and execution of the sanitation and inoculation experiments: chemical and PLFA characterization, Library preparation and bio-informatical analysis of the metabarcoding data and visualization: Statistical analysis. Caroline De Tender: Statistical analysis. Jane Debode: design and execution of the sanitation and inoculation experiments: Library preparation and bio-informatical analysis of the metabarcoding data and visualization. 


\section{Declaration of competing interest}

The authors declare that they have no known competing financial interests or personal relationships that could have appeared to influence the work reported in this paper.

\section{Acknowledgement}

ReGrow4C (Reuse of spent growing media for Circular cultivation of ornamentals) was funded by the Waste Agency of Flanders within the "Vlaanderen Circulair" call, project number 2017-OC-SO 120. Circular Flanders is the hub and the inspirator for the Flemish circular economy. It is a partnership of governments, companies, civil society, and the knowledge community that take action together. Caroline De Tender received a grant of the Research Foundation Flanders (FWO) with application number 12S9418N. The authors thank Kristof Maenhout and Gert De Bondt of ILVO for help with the qPCR analysis and collecting the vine weevils larvae, respectively.

\section{Appendix A. Supplementary data}

Supplementary data to this article can be found online at https://doi.org/10.1016/j.jclepro.2020.124128.

\section{References}

Amberger-Ochsenbauer, S., Jauch, M., Schmitz, H.-J., Meinken, E., 2017. Effect of elemental sulfur and nitrogen form on substrate $\mathrm{pH}$ and growth of Calibrachoa in growing media containing compost high in carbonate. Acta Hortic. 1168, 359-364. https://doi.org/10.17660/ActaHortic.2017.1168.46.

Baevre, O.A., Guttormsen, G., 1984. Reuse of peat bags for tomatoes and cucumbers. Plant Soil 77, 207-214. https://doi.org/10.1007/BF02182924.

Boldrin, A., Hartling, K.R., Laugen, M., Christensen, T.H., 2010. Environmental inventory modelling of the use of compost and peat in growth media preparation. Resour. Conserv. Recycl. 54, 1250-1260.

Bolger, A.M., Lohse, M., Usadel, B., 2014. Trimmomatic: a flexible trimmer for Illumina sequence data. Bioinformatics 30, 2114-2120.

Bongiorno, G., Postma, J., Bünemann, E.K., Brussaard, L., de Goede, R.G., Mäder, P., Tamm, L., Thuerig, B., 2019. Soil suppressiveness to Pythium ultimum in ten European long-term field experiments and its relation with soil parameters. Soil Biol. Biochem. 133, 174-187.

Boyer, C.R., Torbert, H.A., Gilliam, C.H., Fain, G.B., Gallagher, T.V., Sibley, J.L., 2012. Nitrogen immobilization in plant growth substrates: clean chip residual, pine bark, and peatmoss. International Journal of Agronomy 2012. https://doi.org/ 10.1155/2012/978528, 2012: Article ID 978528.

Brinton, W.F., 2001. How compost maturity affects plant and root performance in container grown media. Bio-Dynamics 22-27.

Buamscha, M.G., Altland, J.E., Sullivan, D.M., Horneck, D.A., McQueen, J.P.G., 2008. Nitrogen availability in fresh and aged douglas fir bark. HortTechnology 18, 619-623.

Callahan, B.J., McMurdie, P.J., Rosen, M.J., Han, A.W., Johnson, A.J., Holmes, S.P., 2016. DADA2: high-resolution sample inference from Illumina amplicon data. Nat. Methods 13, 581-583.

Carlile, B., Schmilewski, G., 2010. Life in growing media: the good, the bad and the ugly? Proceedings of the International Peat Symposium: Life in Growing Media, pp. 7-14.

Carlile, W.R., Wilson, D.P., 1990. Microbial activity in growing media-a brief review. In: II Symposium on Horticultural Substrates and Their Analysis, XXIII IHC 294, pp. 197-206. September.

Carrión, C., García de la Fuente, R., Fornes, F., Puchades, R., Abad, M., 2008. Acidifying compost from vegetable crop wastes to prepare growing media for containerized crops. Compost Sci. Util. 16, 20-29.

Celikel, G., Caglar, G., 1999. The effects of re-using different substrates on the yield and earliness of cucumber on autumn growing period. Acta Hortic. 492, 259-264.

Costello, R.C., Sullivan, D.M., Bryla, D.R., Strik, B.C., Owen, J.S., 2019. Compost feedstock and compost acidification affect growth and mineral nutrition in northern highbush blueberry. HortScience horts 54 (6), 1067-1076.

de Kreij, C., Sonneveld, C., Warmenhoven, M.G., Straver, N., 1992. Normen voor gehalten aan voedingselementen van groenten en bloemen onder glas. Research report Proefstation voor Tuinbouw onder Glas. Voedingsoplossingen glastuinbouw no 15, 69p.

De Tender, C., Debode, J., Vandecasteele, B., D’Hose, T., Cremelie, P., Haegeman, A., Ruttink, T., Dawyndt, P., Maes, M., 2016. Biological, physicochemical and plant health responses in lettuce and strawberry in soil or peat amended with biochar. Appl. Soil Ecol. 107, 1-12.
Diara, C., Incrocci, L., Pardossi, A., Minuto, A., 2012. Reusing greenhouse growing media. Acta Hortic. 927, 793-800.

García de la fuente, R., Carríon, C., Botella, S., Fornes, F., Noguera, V., Abad, M., 2007. Biological oxidation of elemental sulphur added to three composts from different feedstocks to reduce their $\mathrm{pH}$ for horticultural purposes. Bioresour. Technol. 98 (18), 3561-3569.

Giuffrida, F., Consoli, S., 2016. Reusing perlite substrates in soilless cultivation: analysis of particle size, hydraulic properties, and solarization effects. J. Irrigat. Drain. Eng. 142, 04015047 https://doi.org/10.1061/(ASCE)IR.19434774.0000968.

Grigatti, M., Cavani, L., Ciavatta, C., 2011. The evaluation of stability during the composting of different starting materials: comparison of chemical and biological parameters. Chemosphere 83, 41-48.

Harris, D.C., Yang, J.R., Ridout, M.S., 1993. The detection and estimation of Verticillium dahliae in naturally infested soil. Plant pathology 42 (2), 238-250.

Iglesias-Díaz, M.I., Lamosa, S., Rodil, C., Díaz-Rodríguez, F., 2009. Root development of Thuja plicata in peat-substitute rooting media. Sci. Hortic. 122, 102-108.

Jackson, B.E., Wright, R.D., Alley, M.M., 2009. Comparison of fertilizer nitrogen availability, nitrogen immobilization, substrate carbon dioxide efflux, and nutrient leaching in peat-lite, pine bark, and pine tree substrates. Hortscience 44, 781-790.

Jeffers, S.N., Martin, S.B., 1986. Comparison of two media selective for Phytophthora and Pythium species. Plant Dis. 70 (11), 1038-1043.

Jiménez, S., Plaza, B.M., Segura, M.L., Contreras, J.I., Lao, M.T., 2012. Peat substrate reuse in lilium "helvetia" crop. Commun. Soil Sci. Plant Anal. 43 (1-2), 243-250. https://doi.org/10.1080/00103624.2011.638585.

Joos, L., Herren, G.L., Couvreur, M., Binnemans, I., Oni, F.E., Höfte, M., Debode, J., Bert, W., Steel, H., 2020. Compost is a carrier medium for. Trichoderma harzianum. BioControl 1-13. https://doi.org/10.1007/s10526-020-10040-z.

Kraska, T., Kleinschmidt, B., Weinand, J., Pude, R., 2018. Cascading use of Miscanthus as growing substrate in soilless cultivation of vegetables (tomatoes, cucumbers) and subsequent direct combustion. Sci. Hortic. 235, 205-213.

Kõljalg, U., Nilsson, R.H., Abarenkov, K., Tedersoo, L., Taylor, A.F.S., Bahram, M., et al., 2013. Towards a unified paradigm for sequence-based identification of fungi. Mol. Ecol. 22, 5271-5277. https://doi.org/10.1111/mec.12481.

López-Escudero, F.J., Mwanza, C., Blanco-López, M.A., 2006. Production of homogeneous and viable Verticillium dahliae microsclerotia effective for Verticillium wilt studies. Biotechnology 5 (4), 421-428.

Lopez-Mondejar, R., Antón, A., Raidl, S., et al., 2010. Quantification of the biocontrol agent Trichoderma harzianum with real-time TaqMan PCR and its potential extrapolation to the hyphal biomass. Bioresour. Technol. 101, 2888-2891. https://doi.org/10.1016/j.biortech.2009.10.019.

Lohr, D., Woeck, C., Meinken, E., 2017. Use of ergosterol as an indicator for colonization of peat-based growing media by saprophytic fungi. Eur. J. Hortic. Sci. 82, 3-11. https://doi.org/10.17660/eJHS.2017/82.1.1.

McMurdie, P.J., Holmes, S., 2013. Phyloseq: an R package for reproducible interactive analysis and graphics of microbiome census data. PloS One 8 (4), e61217.

Martin, M., 2011. Cutadapt removes adapter sequences from high-throughput sequencing reads. EMBnet. journal 17 (1), 10-12.

Meyer, D., Buchta, C., 2019. proxy: Distance and Similarity Measures. URL. https:// CRAN.R-project.org/package=proxy.

Montero, J.I., Antón, M.A., Torrellas, M., Ruijs, M., Vermeulen, P., 2009. EUPHOROS Deliverable 5. Report on environmental and economic profile of present greenhouse production systems in Europe. European Commission FP7 RDT Project Euphoros (Reducing the need for external inputs in high value protected horticultural and ornamental crops). http://www.euphoros.wur.nl/UK.

OEPP/EPPO, 2008. Guidelines for the management of plant health risks of biowaste of plant origin OEPP/EPPO. Bulletin OEPP/EPPO Bulletin 38, 4-9.

Oksanen, J., Blanchet, G., Kindt, R., Legendre, P., Minchin, P.R., O'Hara, R.B., Simpson, G.L., Solymos, P., Stevens, M.H.M., Szoecs, E., Wagner, H., 2010. Vegan: community ecology Package. R package version 2.0-10. Available at: http:// CRAN.R-project.org/package $=$ vegan.

Postma, J., Os, E.V., Bonants, P.J.M., 2008. Pathogen detection and management strategies in soilless plant growing systems. In: Soilless Culture, Editor(s): Michael Raviv, J. Heinrich Lieth. Elsevier, ISBN 9780444529756, pp. 425-457. https://doi.org/10.1016/B978-044452975-6.50012-5.

Quast, C., Pruesse, E., Yilmaz, P., Gerken, J., Schweer, T., Yarza, P., Peplies, J., Glöckner, F.O., 2013. The SILVA ribosomal RNA gene database project: improved data processing and web-based tools. Nucleic Acids Res. 41, D590-D596.

R Core Team, 2019. R: a language and environment for statistical computing. $\mathrm{R}$ Foundation for Statistical Computing, Vienna, Austria. URL. http://www.Rproject.org/.

Recchia, L., Sarri, D., Rimediotti, M., Boncinelli, P., Vieri, M., Cini, E., 2013. Environmental benefits from the use of the residual biomass in nurseries. Resour. Conserv. Recycl. 81, 31-39.

Schmilewski, G., 2017. Growing media constituents used in the EU in 2013. Acta Hortic. 1168, 85-92. https://doi.org/10.17660/ActaHortic.2017.1168.12.

Soumaré, M., Demeyer, A., Tack, F.M.G., Verloo, M.G., 2002. Chemical characteristics of Malian and Belgian solid waste composts. Bioresour. Technol. 81, 97-101.

Uhlírová, E., Elhottová, D., Tř́íska, J., Šantrůčková, H., 2005. Physiology and microbial community structure in soil at extreme water content. Folia Microbiol. 50, $161-166$.

Urrestarazu, M., Mazuela, P.C., Martınez, G.A., 2008. Effect of substrate reutilization on yield and properties of melon and tomato crops. J. Plant Nutr. 31, 2031-2043. 
van Loenen, M.C.A., Turbett, Y., Mullins, C.E., Feilden, N.E.H., Wilson, J.W., Leifert, C., Seel, W.E., 2009. Low temperature-short duration steaming of soil kills soilborne pathogens, nematode pests and weeds. Eur. J. Plant Pathol. 109, 993-1002.

Van Soest, P.J., Robertson, J.B., Lewis, B.A., 1991. Methods for dietary fiber, neutral detergent fiber, and nonstarch polysaccharides in relation to animal nutrition. J. Dairy Sci. 74, 3583-3597.

Vandecasteele, B., Debode, J., Willekens, K., Van Delm, T., 2018a. Recycling of P and K in circular horticulture through compost application in sustainable growing media for fertigated strawberry cultivation. Eur. J. Agron. 96, 131-145. https:// doi.org/10.1016/j.eja.2017.12.002.

Vandecasteele, B., Muylle, H., De Windt, I., Van Acker, J., Ameloot, N., Moreaux, K., Coucke, P., Debode, J., 2018b. Plant fibers for renewable growing media: potential of defibration, acidification or inoculation with biocontrol fungi to reduce the $\mathrm{N}$ drawdown and plant pathogens. J. Clean. Prod. 203, 1143-1154. https://doi.org/10.1016/j.jclepro.2018.08.167.

Vanden Nest, T., Vandecasteele, B., Ruysschaert, G., Cougnon, M., Merckx, R., Reheul, D., 2014. Effect of organic and mineral fertilizers on soil P and C levels, crop yield and P leaching in a long term trial on a silt loam soil. Agric. Ecosyst. Environ. 197, 309-317.

Vanden Nest, T., Amery, F., Fryda, L., Boogaerts, C., Bilbao, J., Vandecasteele, B., 2020.
Renewable P sources: P use efficiency of digestate, processed animal manure, compost, biochar and struvite. Science of The Total Environment. https:// doi.org/10.1016/j.scitotenv.2020.141699, 141699.

Veijalainen, A.-M., Juntunen, M.-L., Lilja, A., Heinonen-Tanski, H., Tervo, L., 2007. Forest nursery waste composting in windrows with or without horse manure or urea - the composting process and nutrient leaching. Silva Fenn. 41, 13-27.

Viaene, J., Reubens, B., Willekens, K., Van Waes, C., De Neve, S., Vandecasteele, B., 2017a. Potential of chopped heath biomass and spent growth media to replace wood chips as bulking agent for composting high $\mathrm{N}$-containing residues. J. Environ. Manag. 197, 338-350.

Viaene, J., Agneessens, L., Capito, C., Ameloot, N., Reubens, B., Willekens, K., Vandecasteele, B., De Neve, S., 2017b. Co-ensiling, co-composting and anaerobic co-digestion of vegetable crop residues: product stability and effect on soil carbon and nitrogen dynamics. Sci. Hortic. 220, 214-225. https://doi.org/ 10.1016/j.scienta.2017.03.015.

Yoon, H.S., Hwang, Y.H., An, C.G., Hwang, H.J., Shon, G.M., 2007. Effects of reuse of organic substrate on growth and yield of strawberry in soilless culture. Acta Hortic. 761, 521-526. https://doi.org/10.17660/ActaHortic.2007.761.72.

Zucchi, P., Longa, C.M.O., Bertoldi, D., Martinatti, P., Pantezzi, T., 2017. Effects of organic substrate reuse on growth and yield of everbearing 'Capri'strawberry. Acta Hortic. 1156, 579-586. https://doi.org/10.17660/ActaHortic.2017.1156.86. 